\title{
Sociotechnical Context and Agroecological Transition for Smallholder Farms in Benin and Burkina Faso
}

\author{
Parfait K. Tapsoba ${ }^{1}$, Augustin K. N. Aoudji ${ }^{1}$, Madeleine Kabore ${ }^{2}$, Marie-Paule Kestemont ${ }^{3}$, \\ Christian Legay ${ }^{4}$ and Enoch G. Achigan-Dako ${ }^{5, *}$
}

1 School of Economics, Socio-Anthropology and Communication for Rural Development (EESAC), Faculty of Agronomic Sciences (FSA), University of Abomey-Calavi (UAC), 03 BP 2819 Cotonou, Benin;

tapsobakparfait@yahoo.fr (P.K.T.); augustin.aoudji@gmail.com (A.K.N.A.)

2 Institut des Sciences des Sociétés (INSS), Centre National de la Recherche Scientifique et Technologique (CNRST), 09 BP 355 Ouagadougou 09, Burkina Faso; kmado64@yahoo.fr

3 UCLouvain (UCL), Place des Doyens 1, 1348 Louvain-la-Neuve, Belgium; marie-paule.kestemont@uclouvain.be

4 Autre Terre, Organisation Non Gouvernementale (ONG) du Groupe Terre, 01 BP 417301 Ouagadougou, Burkina Faso; christian.legay@autreterre.org

5 Laboratory of Genetics, Biotechnology and Seed Science (GBioS), Faculty of Agronomic Sciences (FSA), University of Abomey-Calavi (UAC), Abomey-Calavi, 01 BP 526 Cotonou, Benin

* Correspondence: enoch.achigandako@uac.bj; Tel.: +229-9539-3283

Received: 25 July 2020; Accepted: 9 September 2020; Published: 22 September 2020

\begin{abstract}
West Africa is facing the challenge of its population's food insecurity in a context of accelerated degradation of natural resources. In order to efficiently face this double bottleneck, agroecological interventions were implemented as a way to promote best agricultural practices. Agroecology is a mode of production that nowadays questions our food system which, despite technological progress, still struggles to feed the world's population. This systematic review is part of the vision of a deep agroecology and aims at analyzing the institutional, political, organizational, and social obstacles and levers for an agroecological transition and its amplification in Burkina Faso and Benin. For this purpose, a structured literature review was conducted using grey and published literature. It appears that despite the mitigated results of the implementation of the Green Revolution model of agricultural production in West Africa, African public authorities seem to have placed once again their faith in conventional production practices to respond to the challenges facing agriculture in the region. This situation goes beyond the regional framework to take root at the national level, (e.g., Burkina Faso, Benin), with the corollary of an apparent lack of institutional interest in sustainable modes of production. However, there is a network of stakeholders who are developing promising initiatives for scaling up agroecological practices.
\end{abstract}

Keywords: deep agroecology; scaling up; West Africa; territorialized food system; territorial arrangements; sustainability

\section{Introduction}

How can we satisfy "the needs of the present without compromising the ability of future generations to meet their own needs?" [1]. This is the concern that the humanity must efficiently address today through agroecological intensification of production systems. However, agroecological transition is a major challenge in West Africa [2,3]. Thus far, agriculture represents a prominent economic sector in this region. It generates more than $30 \%$ of the regional Gross Domestic Product (GDP) and employs more than $60 \%$ of the active population [4]. Despite the overwhelming majority of the population engaged in the agricultural sector, the region is facing a succession of food and nutritional crises of 
increasing frequency and magnitude [4,5]. With around 391 million inhabitants, the region represents $5.06 \%$ of the world's population and more than $6 \%$ of the world's undernourished people [5-7]. Most of these people are farmers, most of whom live in rural areas [8]. This situation is amplified by the degradation of natural resources (e.g., water, agricultural land, vegetation) at the regional level, aggravated by climate change $[9,10]$. With more than $20 \%$ of land already degraded in most countries of the region, soil degradation, mainly expressed in the form of erosion, is one of the root causes of the stagnation or decline in agricultural productivity [11]. This situation is rooted in agricultural land clearance, heavy rains, mechanical tillage, which leads to the destruction of the environmental functions of the soil, the reduction of biodiversity and ever-increasing use of herbicides, fertilizers, and pesticides in order to increase or maintain yields until the total collapse of the soil system and the production base [12]. In addition to these factors, there is the problem of large-scale land grabbing driven by agribusiness, which negatively influences the food situation $[13,14]$. The region is also facing a decrease in the diversity of its plant genetic resources caused by unsustainable agricultural practices, such as shifting cultivation, expansion, and reliance on monocultures [15]. However, with its population which doubles every 20-25 years, West Africa is expected to feed 500 million citizens in 2030 and 796 million people in $2050[4,7]$.

In prevention of food shortage due to demographic explosion, the agro-industrial productivist methods were introduced in Latin America, Asia and Africa as early as the 1950s under the impetus of the "green revolution" to meet the ever-increasing food needs of the population [16]. The main objective of that policy was to increase agricultural yields in order to fight hunger and, indirectly, poverty through the use of improved seeds, mainly high-yielding hybrids, massive use of chemical inputs (fertilizers, pesticides) from petrochemicals, and crop irrigation [17-19]. Between 1960 and 1990, this production method effectively increased yields in some regions of the world, such as Latin America, where maize and wheat yields increased by $72 \%$; and India, where agricultural productivity of wheat and rice in the state of Punjab increased by about $6 \%$ per year in the two decades following the Green Revolution [20,21]. However, after a short-lived success, the Green Revolution very quickly showed its limits in both agronomic, environmental and social terms [16,21,22]. Several studies showed a significant stagnation in crop yields $[21,23,24]$. The maintenance of yields is essentially achieved "through a real technical relentlessness essentially based on the increase in the doses of chemical fertilizers" [25]. This situation strongly contributes to soil pollution, considerable reduction of biodiversity, and a dependence of farmers on pesticide and fertilizer manufacturers and external seed suppliers (improved and/or hybrid) [16,26,27].

While in India, for instance, the Green Revolution has helped to make the country one of the world's biggest producers, this apparent success hides the vulnerability of a large proportion of the country's farmers. Indeed, in half a century (1960-2013) the production of food grains, especially rice and wheat, tripled from 82 million to 263.2 million tons [28]. However, based on the expansion of high-yielding seed varieties, irrigation, and fertilizers, this green revolution has been applied only in favorable regions, namely valleys and other irrigable lands, thus relegating most of the drylands to the background [29]. Thus, the improvement in yields has not been evenly distributed throughout the country [28]. Moreover, in the areas where it has been implemented, such as Punjab, farmers have abused chemical fertilizers and pesticides, changed the crop rotation, and drew unreservedly from the water tables in order to produce more [21]. For some farmers, attempts to modernize agriculture by shifting from food crops to well-irrigated cash crops have led to groundwater depletion and over-indebtedness, often resulting in suicide [29]. However, as early as 1968, the founding father of the country's Green Revolution alerted by pointing out that "Irrigation without drainage systems risks making soils alkaline or saline. Additionally, the excessive use of pesticides and herbicides can disturb the biological balance". More than 30 years after this warning, he makes an unequivocal observation: "the Green Revolution has led to excesses and industrial agriculture has polluted the environment and made peasants slaves of the agri-food companies, which push them to consume" [30]. 
This agrarian reform, despite its considerable macroeconomic performances, has created in this country a rural society dominated by a class of powerful notables under whom live a class of smallholders, microfund farmers or sharecroppers, while a proletariat of agricultural workers depends on the goodwill of the owners who employ them and of whom they are often creditors for life [29]. Thus, as stated by the global rainforest movement, in some parts of the world, "the Green Revolution has not only failed to solve the problem of world hunger but has worsened it, contributing to the loss of livelihoods of rural communities and their eviction to urban areas" [31]. Moreover, this model highlighted the specialization of regions that enabled comparative advantages to be profiled on the world market by exporting cash crops and importing non-competitive crops [32], thereby exacerbating global warming with more greenhouse gas emissions (e.g., transport, logistics such as cold rooms). Agriculture and industrial food systems based on this model have thus become trapped in a set of vicious circles [27]. They are part of a linear and degenerative industrial process that captures, transforms, uses, and then rejects the planet's resources, on the one hand, by fueling deforestation (particularly in African countries where institutional weaknesses often impede the efficient management of forest resources), the combustion of fossil fuels and the massive use of fertilizers, and, on the other hand, by generating carbon dioxide and other pollutants [33]. In the same vein, about $14 \%$ of harvests are nowadays lost, thus accentuating the footprint of agriculture in the degradation of natural resources [34].

Climate change and land degradation are now at the center of the challenges facing agriculture, which today is both a victim and an actor of these phenomena [25,35]. Raworth [33], in her book "Doughnut Economics", has showed the need to place humanity's drain on the planet's resources between a lower threshold called "social foundation" below which critical human deprivation is observed and an "ecological ceiling" beyond which critical degradation of the planet occurs. Nowadays, it has, therefore, become imperative to keep this social foundation threshold below the ecological ceiling in order to avoid critical degradation of the planet. Thus, the environmental, social, and technical limits of the Green Revolution model will contribute to the emergence of new and revised forms of agriculture that are considered more sustainable for food security and environmental preservation [24]. Among these sustainable production methods, agroecology [36,37] features prominently. It is a strategic approach that allows for a successful transition towards more sustainable agricultural and food systems [38]. From the agricultural model promoted by the green revolution to that of agroecology, people are moving from a prescriptive "top-down" logic of technical change, based on the implementation of standardized technical packages, to an innovation logic supported by a network of various stakeholders, including the farmers themselves, based on the analysis of local contexts and needs, and the development of the most appropriate biological, technical and institutional solutions on a territorial scale [39]. This vision is increasingly being included in major international development agendas such as the 2030 sustainable development goals [40,41].

Several agroecological experiments were successfully implemented in West Africa [3]. However, in spite of the commitment of the agroecological transition stakeholders, agroecological initiatives remain local, isolated, and are still struggling to change scale [3,42-44]. This situation leads to some questions that deserve clarification, because, it is necessary to know the nature of things in order to create a dynamic of change [45]. Those questions include: (i) What transition model do we need between the diversity of approaches and implications for West Africa? (ii) What is the institutional and political environment in which the issue of agroecological transition arises? (iii) Who are the stakeholders of this transition and what are their constraints? (iv) What are the opportunities and levers for a regional agroecological transition? This review examines those issues in the agrosociological contexts of Benin and Burkina Faso in order to consider the diversity of agrosystems and better explore all facets of the agroecological transition. The two countries are respectively coastal and continental Sahelian countries. The general objective of the review is to propose guidelines scaling up agroecology by diagnosing the individual, social, economic, institutional and political factors that influence agroecological production in Benin and Burkina Faso. More specifically, it is about: (i) capturing a vision of the agroecological transition in West Africa and defining an approach; (ii) analyzing the socio-technical environment of 
agriculture in the region as well as the constraints and transition prospects it offers; (iii) inventorying the main agroecological transition stakeholders in the region and establishing their organizational dynamics; (iv) analyzing cross-cutting issues, including gender, land tenure, and market opportunities, which may influence the agroecological transition; and, finally, (v) proposing guidelines for scaling up the agroecological transition in Benin and Burkina Faso.

\section{Materials and Methods}

The systematic review method proposed by Lampridi et al. [46] was used to suggest ways to scale up agroecological transition. This method is particularly adapted to studies on agricultural sustainability. It involves two levels of analysis: the phase of data collection, and the phase of data analysis. This two-level of analysis makes systematization, data mining, and methodological analysis easier [46].

\subsection{Data Collection Phase}

\subsubsection{Primary Data}

Primary data collection was conducted in the academic literature, but also in the practitioner-oriented literature commonly referred to as "grey literature". This primary data collection method was used by Velten et al. [47] in their systematic review "What is Sustainable Agriculture?" Academic publications were searched in the Scopus search engine, and Google Scholar. On Scopus, the composite field Title-Abs-Key for abstracts, keywords and article titles was used with the keywords "transition agroecology", "principles and objectives of agroecology", "scaling up agroecology", "theoretical approaches to agroecological transition", "agricultural sector in Africa", "stakeholders of agroecological transition in Africa", "/challenges/constraints to agroecological transition in Africa", "opportunities/levers/tracks/assets for an agroecological transition in Africa", "soil fertility management", "biological pest control", "integrated management of natural resources". On Google Scholar, these keywords were directly entered into the search engine. This allowed the inventory of all research articles, systematic review articles, book chapters, peer-reviewed books available in the search engines at the time of the search. Grey literature was searched directly in the Google search engine using the previous keywords, and included non-peer-reviewed documents, including publications without International Standard Book Number (ISBNs) or International Standard Serial Number (ISSNs), such as websites or reports that are more geared towards agroecological practitioners, decision-makers, etc. All searches (academic documents or grey literature) concerned documents published in French and English up to the present day.

\subsubsection{Primary Analysis}

The initial search generated 416 documents which contained the keywords searched (179 academic documents and 237 grey literature documents). This initial sample was then exported to Mendeley [48] for a first screening. Duplicates as well as a number of documents were removed on the basis of our inclusion and exclusion criteria (Table 1). 
Table 1. Key search words and inclusion/exclusion criteria.

\begin{tabular}{|c|c|c|}
\hline Key Words & Inclusion & Exclusion \\
\hline Agroecological transition & $\begin{array}{l}\text { Addresses the transition of the farm } \\
\text { and the territory }\end{array}$ & Does not concern the field of Agriculture \\
\hline Scaling up agroecology & Proposes an approach & Not in line with a deep sustainability approach \\
\hline Theoretical approaches to agroecological transition & Scientific production of the last 20 years & Grey literature \\
\hline $\begin{array}{c}\text { Stakeholders in the agroecological transition in } \\
\text { west Africa }\end{array}$ & $\begin{array}{l}\text { the dynamics of agroecological } \\
\text { stakeholders in west Africa }\end{array}$ & $\begin{array}{l}\text { Does not give precise details on the role and } \\
\text { organization of the stakeholders }\end{array}$ \\
\hline $\begin{array}{c}\text { Soil fertility management } \\
\text { Biological pest control } \\
\text { Integrated management of natural resources }\end{array}$ & $\begin{array}{l}\text { Address to West Africa, and or at least } \\
\text { one West African country }\end{array}$ & $\begin{array}{l}\text { Do not provide enough detail on the West } \\
\text { African context }\end{array}$ \\
\hline
\end{tabular}

This first stage produced 206 documents (80 academic documents and 126 grey literature documents) with following lexicometric distribution of titles (Figure 1): classes 2 and 4 group words from the titles of documents related to the socio-technical context of Burkina Faso and Benin, while classes 1,3, and 5 concern documents related to the scaling up of the agroecology in these countries.

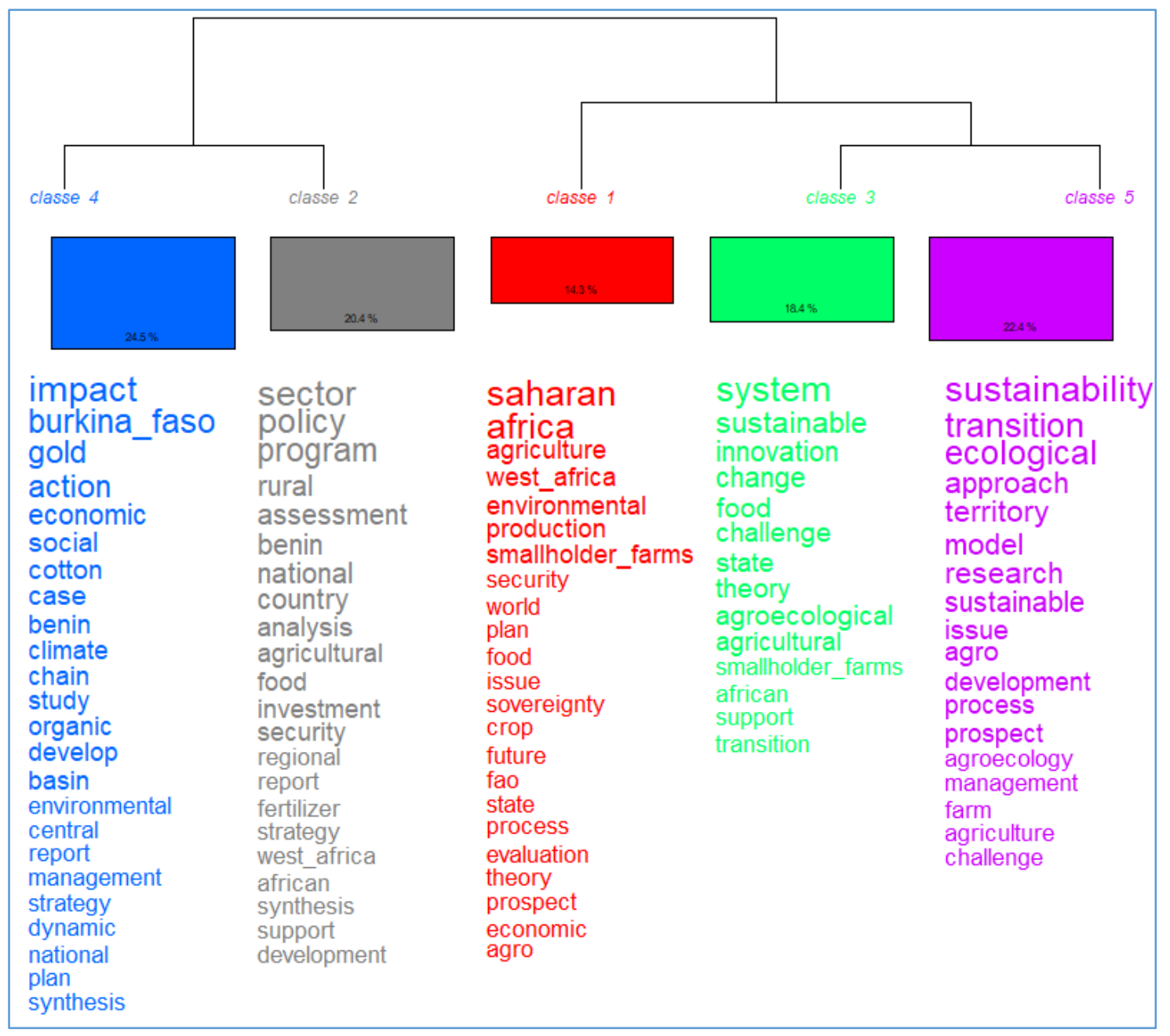

Figure 1. Global lexicometric overview of used documents' titles.

\subsection{In-Depth Data Analysis}

The 206 papers that met the relevant criteria after the selection of titles and abstracts based on our inclusion and exclusion criteria (Table 1) were critically reviewed in order to build on the fundamentals 
of agroecology and its objectives, to attribute content to agroecology in the West African context, and to adopt a theoretical approach to this transition.

This semantic and conceptual clarification enabled us to orient the diagnosis of the socio-technical context (agrarian, institutional and political context, organization of the stakeholders of the transition, and finally cross-cutting considerations, such as land tenure, gender, and agroecological production valorization) towards the search for approaches adapted to the regional context. The organization of this work, which sets out the conceptual framework for the analysis is shown in Figure 2.

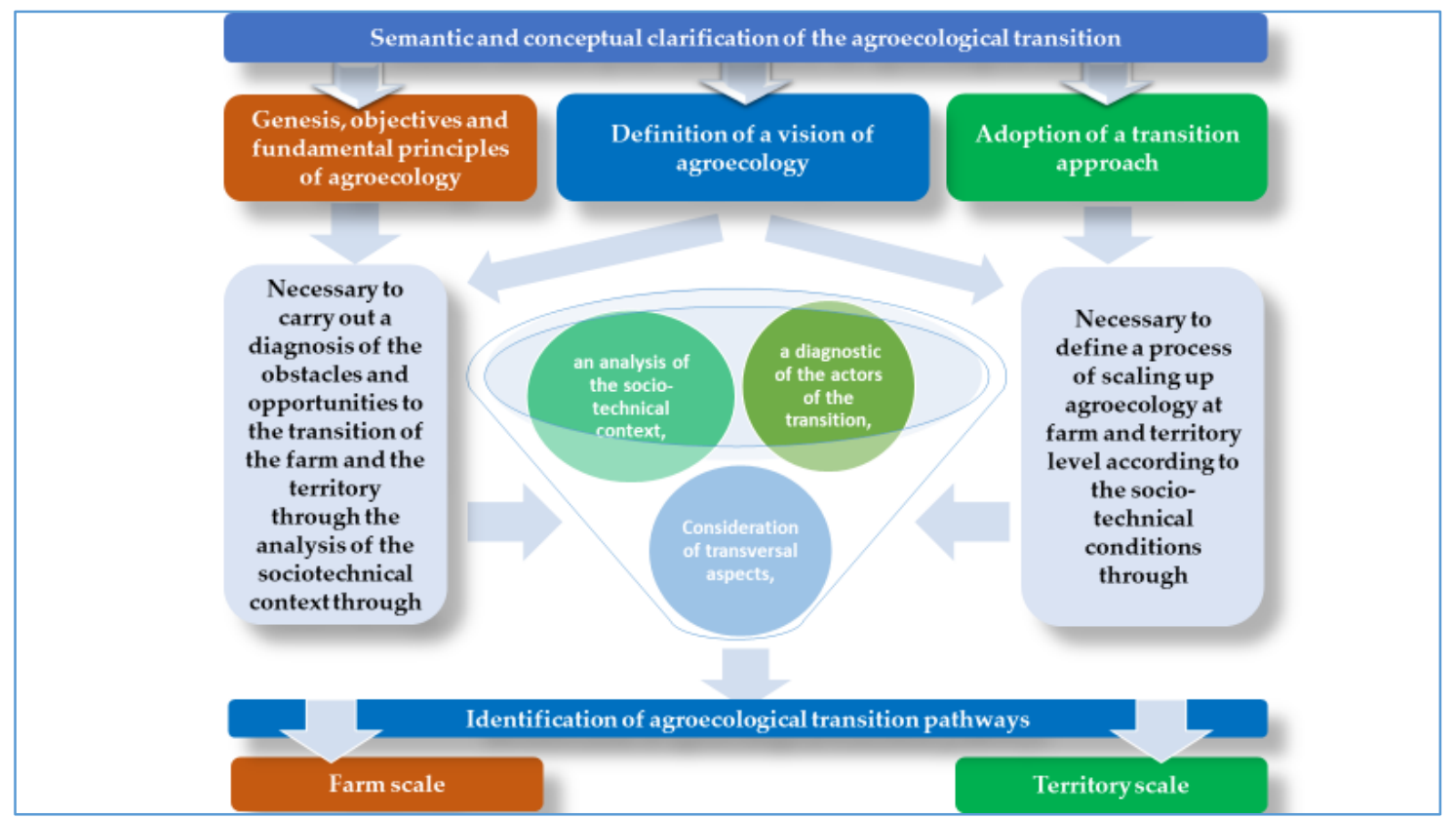

Figure 2. Research conceptual framework.

\section{The Fundamental Need for a Semantic and Conceptual Clarification of the Agroecological Transition}

\subsection{Genesis of a Holistic Concept: Objective and Principles}

Agroecology is the result of many currents coming from different countries [49]. The term "agroecology" was first used in 1928 by a Russian agronomist, Basil M. Bensin (1881-1973), to designate an approach to agronomy that draws on ecological knowledge by considering living organisms as a "system" of interacting and dynamic communities [50]. Between the 1930s and 1960s, related studies [51-54] were published [55] and addressed agroecology without mentioning the term in their titles. However, the concept did not emerge until a few years later with the publication in 1965 of the first book entitled "Agroecology" by the German ecologist and animal scientist Tischler [49]. His approach combines ecology and agronomy, with an emphasis on the integration of agricultural management [55]. Starting in the 1970s, agroecology, in addition to being a scientific discipline, gradually appeared from the 1980s onwards, both as a movement and as a set of practices [55]. Several researchers from American universities contributed to the evolution of the concept. Indeed, most of them were biologists and ecologists who questioned the ecological sustainability of agriculture $[36,37,56-58]$. However, it is from their meeting with social science researchers who were concerned about the social determinants of agricultural practices $[59,60]$ that the concept will evolve towards its current acceptance: a science, agricultural practices and a social movement [55,61].

Agroecology combines different approaches to solve the current challenges in agricultural production [55]. As a practice, it refers to a set of agricultural methods and techniques (agroforestry, conservation agriculture, polycultures, biological pest control, direct seeding under plant cover, 
crop-livestock integration, organic farming, etc.) that allow the optimization of agricultural systems by imitating "natural processes", through a significant reduction of external inputs and the preservation of "key immune, metabolic and regulatory processes of agroecosystems" [22,62,63]. However, far from being confused with these techniques, agroecology tends to encompass them [22] with a common reference point "understanding nature in order to imitate it" [61]. This translates into five principles: (i) optimization of nutrient flows and recycling of biomass; (ii) efficient management of soil organic matter and stimulation of its biotic activity; (iii) reduction of energy, water and air losses through microclimatic management and soil protection; (iv) diversification in time and space of crop species and genetic varieties; (v) and, finally, improvement of beneficial biological interactions and synergies in agroecosystems $[63,64]$. Moreover, beyond a set of agronomic practices, agroecology is also a social movement that advocates, for example, remunerative prices for farmers who are most often the victims of market distortions; the conservation of farmers' seeds and the fight against the use of genetically modified organisms (GMOs) [44]. Finally, it is a scientific discipline whose field of action has gradually shifted from the agroecosystem to the food system [65].

\subsection{For a Deep Agroecology in West Africa}

The term "agroecology" is nowadays a difficult concept to define because of its polysemous nature $[25,66]$. It is characterized by the pursuit of coexistence of several visions, whether in academic terms of research methods or practice [67]. Thus, there is no single agroecology, but a series of historical, geographical, institutional, and social situations in which the term has different meanings [41]. However, let us retain the definition according to which agroecology corresponds to a set of practices based on the mobilization of the ecological functionalities of agrosystems, the optimization of natural processes, and the sober management of resources [39]. For these authors, beyond a set of practices, the agroecological approach "corresponds to a paradigm shift that responds to the concerns of citizens and consumers regarding their nutrition, health, ecosystem health, equity and social and environmental responsibility. It calls for a renewed perception of the performance of production and processing systems, and requires a different logic of innovation". This definition is linked to our shared vision of a deep agroecology, which is itself an extension of deep sustainability [50]. Indeed, deep sustainability and weak sustainability are at the basis of two economic concepts [68] that reflect two opposing visions of the notion of sustainable development [69]. Weak sustainability is based on "the principle of the subordination of the environment to the interests of the human species" [70]. It reflects a form of development in which human beings almost exclusively focus on their well-being [69]. It has a functionalist vision of nature, reduced to its usefulness for economic development [71] and considers that there is substitutability between different forms of capital things, among other things, to technical progress [72].

From this point of view, the degradation of the environment (natural capital) is not a problem if it can be compensated in its capacity to produce utility by various artifacts [68]. The reduction in natural capital (e.g., air, water, soil, landscape, biodiversity) can, therefore, be compensated by an increase in physical capital (e.g., infrastructure, buildings, savings, machines) of equal value [73]. Deep sustainability, on the contrary to weak sustainability, is a more appropriate way to fully integrate the imperatives of environmental protection and inter and intra-generational equity in the functioning of the economy [68]. It argues that economic, human, and biological resources are not interchangeable and suggests that there is a threshold of "critical natural capital" $[58,68]$. The difference between weak and deep sustainability goes beyond a simple question of appreciation or degree. It represents a real conceptual divide in terms of confidence in the virtues of technical progress [74]. The vision of deep agroecology thus derives from the notion of strong sustainability. It is based on the principle that agricultural practices are integrated into the general functioning of societies [50]. This requires a more systemic approach by rethinking the agri-food system as a whole $[67,75,76]$. As stated by Calame [50], deep agroecology is a "profound reform from farm to fork, from production to consumption patterns, through public policies". 
In practice, this approach emphasizes increasing biological diversity at different spatial scales (from plot to landscape) and time (cropping period, crop succession) to promote interactions between plants, animals and microorganisms [76]. It aims to optimize the interactions between plants, animals, humans and the environment, without overlooking the social and economic aspects that need to be taken into account for a sustainable and equitable food system [77]. Deep agroecology promotes participatory research, responsible consumerism, mutualist financing of agriculture that involves consumers, and finally a reform of public agricultural policies, particularly in terms of taxation, market regulation, autonomy and the empowerment of local communities [50]. More than an ecological adjustment of farming practices, it is a major component of food sovereignty, which considers the enhancement of agro-biodiversity as the entry point for redesigning systems that ensure farmers' autonomy and food sovereignty $[22,78]$. This food sovereignty expresses the needs and aspirations of farmers and local communities [2]. It refers to the right of people to healthy and culturally appropriate food produced through ecologically sound and sustainable methods, as well as their right to define their own agricultural and food systems [79]. This implies the autonomy of seeds, which are the first link in the food chain [80]. Thus, in the West African context, while a second Green Revolution was launched following the first one, whose results were disappointing [19,22], deep agroecology is opposed to the agro-industrial model promoted by the Green Revolution and stands out as an alternative agricultural model that results in a radical critique of agrochemicals [22,50,63,81,82]. Questioning the entire food system rather than agricultural practices, deep agroecology represents an opportunity to analyze in a common framework the concerns of farmers and consumers in a generational and intergenerational social equity dynamic. However, its implementation requires a set of prerequisites, including the need to define an approach to agroecological transition.

\subsection{An Agroecological Transition through the Multi-Level Perspective Approach}

The agroecological transition can be defined as a systemic transformation of agriculture and food [76]. The term "Socio-Technical Transitions" (STT) refers to a set of theoretical approaches to ecological transition [83]. Among these approaches, Markard et al. [84] identified four frameworks for analyzing transitions to sustainability: (i) "Strategic Niche Management" based on the analysis of niche creation and support as a driver of regime change [85]; (ii) "Transition Management" interested in how to govern, accompany and promote change in a more sustainable perspective [86,87]; (iii) "Technological Innovation Systems" focusing on the emergence of new technologies and related institutional and organizational changes [88,89]; and, finally, (iv) "Multi-level Perspective", which extends the analysis to larger transitions and interactions between three levels of organization (niche, regimes, landscape) [90-92]. This multi-level perspective is considered to be the most appropriate for analyzing alternative food systems [39]. Indeed, it proposes to analyze in a common framework, the dominant agro-industrial food system that can be assimilated to the sociotechnical diet and the alternative experiences considered as niches. In this regard, niches are not disconnected from the transition model; they are understood as incubation spaces [90], which are places where learning processes are carried out and new economic networks are built. Their role is to house the construction and consolidation of alternative systems [93].

However, it is important to highlight that the socio-technical regime is stable because it is based on a well-established set of norms, stakeholders, policies, markets and research. Niches are built away from dominant rules and stakeholders. According to Geels and Schot [91], in terms of sociotechnical transition, niches tend gradually to integrate the dominant regime by changing its various dimensions (norms, stakeholders, knowledge, etc.). This conception of sociotechnical transition highlights the transformative or non-transformative nature of these innovations towards the dominant model. The multi-level perspective considers the sociotechnical transition as the result of interactions between several levels: the sociotechnical landscape, which covers the environment in which the society is embedded, which is a stable sociotechnical regime, composed of rules, practices and interdependent stakeholders that guide or constrain the actions of operators, niches that can be assimilated to spaces 
where more radical innovations are being built. The transition from one sociotechnical regime to another is the result of pressures exerted by the landscape on the regime or the gradual integration of radical innovations (new rules, new practices) into the regime [90]. In this multi-level perspective of transition, public policy makers can also consider several levers for action. Actions on the standards of the agro-industrial regime can be complemented by specific policy measures targeting niche innovations [39]. These actions can contribute to unlocking the dominant sociotechnical regime governed by rules, norms and stakeholders that make it stable, but at the same time lock it in $[94,95]$.

Thus, by analyzing agriculture as a dominant socio-technical model, The International Panel of Experts on Sustainable Food Systems (IPES-Food) identifies eight factors that contribute to stabilizing and locking it [27]. However, these locks appear differently depending on the situation, including institutional, political, individual, social, and organizational factors [44]. According to these authors, in West Africa, they mainly consist of (i) the lack of political recognition; (ii) the constraints linked to the adoption of new practices; (iii) difficulties in accessing the market; (iv) the lack of consolidation, dissemination and communication of information; and, finally, (v) the scattering of agroecological initiatives. In addition to these obstacles, in West Africa, the gender issue and land tenure are cross-cutting considerations that are just as crucial to the agroecological transition process and that should be analyzed.

\section{The Socio-Technical Environment of the Agroecological Transition in West Africa}

\subsection{The Context: A Strong Link between the Regional Situation and National Contexts}

\subsubsection{Institutional and Political Context}

Regional Overview

Public policies have an important role to play in the process of agroecological transitions within a territory $[39,66,96]$. In West Africa, since independence, agricultural policies have undergone a radical transformation in their objectives, moving from policies of "resource extraction to economic growth drivers" [10]. However, in practice, the results have remained mitigated. Indeed, from national interventionist policies to regional integration policies and structural adjustment, the changes have not always produced the expected results $[97,98]$. In the 1960s and 1990s, agricultural development policies in West Africa focused on increasing production in order to guarantee food security for the population and provide foreign exchange for the states (e.g., "cotton, groundnut, sesame exports") [23]. In the 1990s, driven by structural adjustment programs, they focused on export crops such as cotton, the only crop capable of producing a rapid return on investment [99]. After a long period of neglect of agriculture during the 1980s and 1990s, policies in the region became more favorable to agricultural growth since the 2000s [10]. This will be reflected at the continental level by the implementation of the New Partnership for Africa's Development (NEPAD) and its common agricultural policy: The Comprehensive Africa Agriculture Development Program (CAADP) [100]. The implementation of this agricultural policy is supported by research institutes such as the Forum for Agricultural Research in Africa (FARA), which is the highest agency for agricultural research in Africa, and the West and Central African Council for Agricultural Research and Development (CORAF-WECARD), which groups national agricultural research systems and coordinates agricultural research in West and Central Africa [101]. These two institutions operate respectively at the continental and regional levels in the implementation of CAADP component 4, which is a major component of this policy and is based on increasing agricultural productivity through research and development [102].

Nowadays, in a dynamic of regional integration, the major agricultural orientations are given at the continental and regional levels and play an important role in national agricultural policies [100]. Thus, as members of the Economic Community of West African States (ECOWAS), the agricultural policies of Benin and Burkina Faso are strongly influenced by the agricultural policy of this institution: "The Agricultural Policy of the Economic Community of West African States" (ECOWAP) [103]. It was 
elaborated in 2005 as an instrument for the implementation of CAADP [104]. Its main objective is to "contribute sustainably to the satisfaction of the population's food needs, to economic and social development and to poverty reduction in the Member States, as well as to the reduction of inequalities between territories, regions and countries" [103]. However, this policy coexists with the agricultural policies of two other regional institutions, namely the Strategic Plan for Sustainable Food Security (CSSA) of the Permanent Inter-State Committee for Drought Control in the Sahel (French acronym: CILSS) and the WAEMU Agricultural Policy (PAU) of the West African Economic and Monetary Union (WAEMU) [105]. Thus, ECOWAS seeks to provide a common platform for effective action to harmonize and integrate the objectives pursued through the various strategies and programs of countries and other intergovernmental organizations in order to avoid duplication of efforts in the pursuit of common objectives $[103,106]$. These regional agricultural policies are not very conducive to agroecology. Rather, they often show a renewed interest in the Green Revolution [23]. Indeed, ECOWAS, in its Common Agricultural Policy, clearly states its priority of agricultural intensification and intensive use of chemical inputs [107].

This objective is so well illustrated in its Regional Strategy for the Promotion of Fertilizers in West Africa (SRPEAO) where it states that "The poor performance of agricultural sectors in Sub-Saharan Africa (SSA) is due to the weak use of external inputs such as fertilizers, the heavy dependence on traditional agricultural practices and the intensification practiced by small farmers seeking better yields". As a result, it aimed to increase fertilizer use in the community from $9 \mathrm{~kg} / \mathrm{ha} / \mathrm{year}$ to $23 \mathrm{~kg} / \mathrm{ha} /$ year over the period 2006-2015 [107]. Moreover, the implementation of ECOWAP is based on two essential pillars, namely the National Agricultural Investment Plans (NAIP) of member countries and the Regional Agricultural Investment Program (RAIP) [10]. The National Agricultural Investment Plans, which reflect the priorities of States and national stakeholders, are however mainly focused on "productive" investments in the agriculture, livestock, fisheries and forestry sub-sectors [97]. Indeed, these national plans were drafted after the 2008 food riots and were strongly influenced by the willingness of states and national stakeholders to find short-term solutions to increase production, particularly through fertilizer subsidies [10]. From 2015 onwards, a second generation of RAIPs and NAIPs emerged. However, in terms of orientations, the observation is that they place agriculture in the region within a productivist dynamic through a desire to "modernize family farms and introduce the private sector" [108]. ECOWAP therefore maintains an ambiguous position between agribusiness and family farming, coupled with a notorious lack of political recognition of agroecology, which tends to discredit this type of agriculture among farmers [44,109].

However, the increasing involvement of farmers' and breeders' organizations such as Network of Farmers' Organizations and West Africa Farmers (French acronym: ROPPA), Association for the Promotion of Livestock in the Sahel and Savannah (French acronym: APESS) and the Réseau Billital Maroobè (RBM) in the process of developing regional common agricultural policies is a major step forward for family farming and agroecological transition in the region [10,109]. Moreover, ECOWAP is a very ambitious policy that remains highly dependent on external funding. Almost all investment expenditures related to the implementation of the second generation of ECOWAP's RAIP came from donors and development partners, with the corollary that funding is directed towards agriculture that favors export crops, high value-added sectors, the external market and growth poles [44,105]. This situation is also reflected at the national level and contributes to the orientation of the national agricultural policies of several states in the region towards a more agribusiness-oriented model [109]. West African presidents during their meeting in Malabo in 2014, reaffirmed their commitment to achieving the goal of allocating at least $10 \%$ of public expenditures to agriculture to double productivity by 2025 through focusing on inputs, irrigation, and mechanization [97]. This will result is low investments for alternative agricultural models such as agroecology which undeniably seems to be "the poor relation of financing in Africa" [96] and the private sector can play an important role in this regard [2]. Burkina Faso is not an exception to this reality. It is even known as the "Maputo champion" for having complied previous similar Maputo commitments in the past [110]. Regularly confronted 
with the problems of food and nutritional insecurity of its population, Burkina Faso's agricultural policies have most often been part of a productivist dynamic [100].

Institutional and Political Context of Burkina Faso

From its independence until 2000, the Burkinabé State successively pursued interventionist and then voluntarist policies (especially during the 1983 revolution when more than $44 \%$ of public expenditures were allocated to the agricultural sector) before disengaging from the sector in the context of implementing Structural Adjustment Programs (SAPs) $[100,110]$. In the 2000s, with the advent of ECOWAP and the implementation of its Poverty Reduction Strategy Paper (PRSP), the country implemented the Rural Development Strategy (RDS) in 2004, which will be reviewed in 2015 [111]. In 2012, within the framework of its Strategy for Accelerated Growth and Sustainable Development (French acronym: SCADD), the country drew up a first National Rural Sector Program (NRSP), a version of the national agricultural investment plans drawn up by all ECOWAS countries in connection with the regional agricultural policy (ECOWAP) [110]. Under the impetus of the National Economic and Social Development Plan (French acronym: PNDES), the NRSP was subjected to an in-depth evaluation that led to the development of its second version in 2016: The National Rural Sector Program II (NRSP II) covering the period 2016-2020 [111]. This document is considered today as the only operational reference document for the stakeholders of the sector. It operationalizes the sectoral policies, the PNDES and the SDR. It is also the tool for implementing agricultural policies at the African and regional levels [112]. Within the perspective of this new orientation, the ministry in charge of agricultural development has set up an "Agroecology" focal point in charge of coordinating and implementing the ministry's actions in terms of sustainable agricultural development [69]. This is a real political step forward in the country's agroecological transition process.

Institutional and Political Context of Benin

In Benin, agricultural policies have taken several directions from independence to recent times [113]. Indeed, between 1960 and 2006, the country's agricultural policies were successively Marxist (1972 to 1990) and liberal (1990-2006) [114]. More recently, at the beginning of the 2000s, the country established the foundations of its current agricultural policy, which is oriented towards production diversification through the elaboration of fundamental documents such as the Letter of Declaration of Rural Development Policy (French acronym: LDPDR, 1991), the Declaration of Rural Development Policy (DPDR, 1999), the Master Plan for Agricultural and Rural Development (French acronym: SDDAR, 2000), and the Strategic Operational Plan (SOP, 2000) [115-117]. In 2011, on the basis of Benin's Strategic Development Guidelines (2006-2011) and the Growth Strategy for Poverty Reduction (SCRP/2007-2009), the country drew up the Strategic Plan for the Agricultural Sector Recovery (PSRSA), a document that is linked to regional and international agricultural development policies (PAU/UEMOA; ECOWAP/SADC, etc.) [114]. It expired in 2015 and was replaced by the Strategic Plan for the Development of the Agricultural Sector (French acronym: PSDSA) which forms, with the National Agricultural Investment and Food and Nutritional Security Plan (French acronym: PNIASAN 2017-2021), the two reference documents of the country's agricultural policy [58]. Like many national agricultural policies in the region, Benin's agricultural policy, as in Burkina Faso, does not have a specific program dedicated to the development of agroecology in the different agricultural sectors. However, the national platform of farmers' organizations of Benin (French acronym: PNOPPA) and the agroecological federation of Benin are actively advocating for the inclusion of agroecology in Benin's agricultural policy [118]. Furthermore, it is important to recognize that, in practice, the public authorities remain favorable to the implementation of large-scale agroecological initiatives such as the sustainable fertility management project, which includes about 3000 farmers spread across six municipalities of the country [119]. 


\subsubsection{The Agrarian Context}

In the quest for ever-increasing yields, the Green Revolution-inspired model of agricultural production is still the one proposed for farmers and stockbreeders in West Africa [23]. This reality is reflected in the ever-increasing subsidization and use of mineral fertilizers in the countries of the region [120,121]. However, more than $90 \%$ of the region's agricultural production is based on family and subsistence farming [122]. Most of these farms are characterized by family farmers who work with hand tools in small areas $[123,124]$. These characteristics are in stark contrast to the proposed agricultural model which, after more than 60 years, does not seem capable of providing sustainable solutions adapted to the needs and capacities of farmers' families [3]. This situation provides an ideal platform for the development of agroecology. Thus, agroecological initiatives are increasingly being carried out by farmers' organizations (FOs) or non-governmental organizations (NGOs) that organize training courses for their members to initiate and strengthen agroecological practices, with particular emphasis on endogenous farmers' knowledge [125]. However, despite the regional environment, the agrarian context varies from one country to another.

The Agricultural State of Burkina Faso

In Burkina Faso, agricultural activities are characterized by extensive subsistence agriculture dominated $(72 \%)$ by small farms of less than 5 ha, with a low level of mechanization $[126,127]$. It is a low-productivity agriculture highly vulnerable to climate change [128]. Four main agroecological zones can be observed throughout the country: the Sahel with an annual rainfall of less than $400 \mathrm{~mm}$; the sub-Sahel where the rainfall varies between 400 and $700 \mathrm{~mm}$; Northern Sudan with annual rainfall between 700 and $900 \mathrm{~mm}$; and, finally, the Southern Sudanese zone, which is the most rain-fed region with annual rainfall value between 900 and $1200 \mathrm{~mm}$ [9]. Two main seasons mark agricultural activities in these different agroecological zones: a winter season and a hot dry season [129]. Climatic trends show an increase in average temperature, disruption of seasonal cycles and a decrease in annual rainfall [128]. According to these climatic characteristics, the country's production is seasonal and cyclical in nature, with a predominance of rain-fed production characterized by cereal farming, which accounts for most of the agricultural production. The main crops are sorghum, millet, maize, rice and fonio (the most important in terms of production volume) as well as cotton (the most important in terms of economic value), sesame, an export crop that has grown rapidly in recent years, and groundnut and cowpea as legumes $[112,128]$. Off-season production remains mainly market gardening and is generally organized around water points $[69,130]$.

Overall, agricultural activities are slowly diversifying, with the development of new sectors such as horticulture (mainly mango, banana, papaya and citrus fruits) and sesame [110,126,131]. However, except cotton, to which the government has been devoting special attention for a number of years, the other sectors are poorly structured [126]. In addition to agricultural activities, pastoralism and the exploitation of Non-Timber Forest Products (NTFPs) are also well developed in the country. With almost 10 million cattle in the country, this sub-sector generates $20 \%$ of the total GDP, mainly through exports, and remains the second largest contributor to agricultural value-added, after cotton [132,133]. More than $80 \%$ of this livestock farming is, however, carried out according to the transhumant or extensive pastoral system [112]. Furthermore, as a landlocked sub-Sahelian country, the exploitation of NTFPs plays an important role in the national economy [134]. It represents a major component of the strategy of the resilience of rural communities, particularly against extreme phenomena and contributes more than twenty billion XOF per year to the national economy [135]. The most commonly valued species particularly used in agroforestry practices are mainly Acacia macrostachya, Tamarindus indica (tamarind tree), Balanites aegyptiaca (desert date palm), Adansonia digitata (baobab tree), Parkia biglobosa (néré), Saba senegalensis (liana gö̈ne), Vitellaria paradoxa (shea tree), Ziziphus mauritiana (jujube tree), Bombax costatum (red-flowered kapok tree) [135]. 
The Agricultural State of Benin

The rural sector remains a key component of Benin's national economy. It contributes about $36 \%$ of GDP, $75-90 \%$ of export revenues and employs $70 \%$ of the active population [136]. Eight agroecological zones cover the territory according to their relative homogeneity, their climatic and agroecological characteristics, and the cropping systems encountered [137]. Zone 5, also known as the central cotton zone, is the largest area in the country's surface and occupies the entire central part. The north is the second cotton-growing zone (zone 2) followed by three other zones, namely the forest zone (zone 1), the food-producing zone (zone 3), and the hill zone (zone 4). The south of the country is subdivided into three zones called "terre de barre" (zone 6), "pêcherie" (zone 8), and "dépression" (zone 7) [138,139]. Agricultural practices are mainly rain-fed and conducted by small family famers having on average 1.7 ha with a low level of input use [136]. However, farmers in the south of the country benefit from an equatorial climate characterized by an alternating two rainy seasons and a dry season, while the center and the north have a single annual rainy season typical of the tropical climate [140]. The main food crops produced is maize, which accounts for $70 \%$ of cereal production, sorghum, rice, cassava, yams, and groundnuts [136]. Cotton remains the most important cash crop, accounting for $70 \%$ of export earnings. Other no less important crops such as pineapple and oil palm, cashew nuts and shea nuts are also exported. [141]. Market gardening is practiced in all regions of the country, especially in the urban and peri-urban areas of the south [142].

After crop production, animal breeding is the second most important agricultural activity in the country. Livestock farming is predominantly bovine ( $81.2 \%)$, essentially transhumant and concentrated especially in the north, with a Sudano-Sahelian and Sudanian climate. Despite its good performance, however, livestock farming remains undervalued at the national level [143]. Thus, with a nearly straight seafront length of $125 \mathrm{~km}$ long and a vast hydrographic network consisting of four main rivers, fishing and aquaculture are also an important part of agricultural activities, mainly in the south [144]. Forest biodiversity is of particular importance for households in both rural and urban areas. Indeed, entire communities are dependent on forests for basic necessities [145]. However, despite climatic and edaphic conditions favorable to the diversification of agricultural production, Benin still imports massively certain products, such as rice and off-season market garden produce to cover the population's food needs [58].

The agrarian contexts of Benin and Burkina Faso present potentialities and constraints for the agroecological transition that are worth mentioning. The majority of farms are family farms that have not been modernized to any great extent, with cotton, cereals and market gardening predominating $[58,69,126,127,130,136]$. This typology constitutes a major asset for the agroecological transition in that the farms are not yet on an industrial scale. Similarly, the abundance of livestock in Burkina Faso and its distribution over the entire territory is a major asset for the development of agroecology, especially for compost production and the availability of draught animals [132,133]. However, it should be noted that the omnipresence of cotton cultivation in these countries affects food security and the process of transition towards agroecology [146]. Indeed, apart from its undeniable occupation of the land, cotton requires very high financial investment, due to the capital-intensive nature of production, which regularly requires the acquisition of special equipment and expensive inputs. [146]. In Benin, nearly $90 \%$ of all imported pesticides are used for cotton cultivation $[147,148]$. The situation is no more encouraging in Burkina Faso, where fertilizers distributed by the cotton and maize systems represent up to $86 \%$ of the 317,000 tones reported by the country's Ministry of Agriculture [149]. However, in 2018, Burkina Faso and Benin even rose to the rank of sixth and eighth world cotton-exporting countries, respectively [150]. In 2018, Benin even became the largest organic cotton producer in West Africa and the largest conventional cotton producer in Africa in 2019 [151,152]. It is, therefore, obvious that this "inherited crop" [146] still has a bright future ahead of it and that the agroecological transition process in these two countries should therefore integrate this reality. Nevertheless, significant progress can be noted regarding the evolution of this crop with regard to the agroecological transition. 
In Burkina Faso, the National Union of Cotton farmers of Burkina Faso (French acronym: UNPCB) has set up since 2004, an organic cotton cultivation program for women and very poor farmers who do not have the financial resources to meet the cost of inputs [9]. Today, the sector has evolved and led to the opening of the first organic cotton factory in the country and the West African region in 2020 [152]. At the same time, organic cotton production is also developing in Benin. In the municipality of Banikoara in Northern Benin, where more than a third of the national cotton production is grown, organic cotton cultivation has become increasingly popular since its introduction in 2008 by the Association of Valiant and Active Women (French acronym: AFVA) supported by the Organization for the Promotion of Organic farming in Benin (French acronym: OBEPAB) [148]. The growth of organic cotton coupled with the wide and disorderly fluctuations of conventional cotton prices on world markets [146] could be a boon for the conversion of conventional cotton farmers to organic cotton farmers. Given the importance of conventional cotton in the lives of many farmers, this opportunity may be a crucial turning-point in the agroecological transition process in these countries, especially as the demand for organic cotton is increasing worldwide [148]. However, the challenge of farmers' knowledge of the technical itineraries of organic cotton remains to be met to increase the yield per hectare, which is still very low (less than $500 \mathrm{~kg}$ per hectare) compared to that of conventional cotton in order to enable farmers to benefit more from the profitable selling prices of certified organic and fair-trade cotton at the level of these countries [153].

Regarding climate, the presence of a multitude of agroecological zones in Benin and their distribution throughout the country is a major asset for the diversification of production [58,138]. Burkina Faso's Sahelian climate is an ideal environment for the expression of the diversity of agroecological practices. Indeed, from the application of soil recovery techniques (soil water conservation/soil defense and restoration (CES/DRS)) in the arid lands of the north of the country, to the practice of assisted natural regeneration (RNA) for the exploitation of NTFPs, the country remains a privileged area for agroecological initiatives $[42,154,155]$. Mr. Yacouba Sawadogo's prowess is a good illustration of this reality: with the Zaï technic, he created a 15-hectare vegetation park that will contribute to prevent the advance of the desert in the north of the country. As a result, he received the nickname "the man who stopped the desert" and the Right Livelihood Award or the alternative Nobel Prize in 2018 [110]. In general, in the Sahelian zone, more than 700,000 hectares are cultivated in water and soil conservation (CES), particularly in Burkina Faso, Mali, and Niger, while in the Dogon Plateau, the central plateau of Burkina Faso and the Maradi Zinder zone in Niger, nearly 5 million hectares are undergoing "assisted natural regeneration" $[156,157]$. In the same vein, the government of Burkina Faso, in collaboration with the other sahelian countries, has undertaken the Great Green Wall project with a view to curbing the advance of desertification, restoring and enhancing the potential of arid and semi-arid zones, and promoting the conditions for sustainable development [158] However, in Burkina Faso, agrosilvopastoral exploitation is increasingly facing recent developments of the mining sector and its corollary (e.g., loss of agricultural labor to the profile of gold sites, monopolization of agricultural land, environmental pollution) [159-161]. Growing insecurity, especially in the north and east of the country, is also putting a strain on this sector, which is already prone to several difficulties [162].

\subsection{Stakeholders of the Agroecological Transition}

\subsubsection{Organizational Dynamics}

The agroecological transition towards sustainable food systems is a fundamental challenge for the future for all food system stakeholders [163]. In West Africa, several categories of stakeholders are working to promote and support the agroecological transition $[9,155]$. To better coordinate their actions, they have created the Alliance for Agroecology in West Africa (3AO). It is a coordination and information relay platform and is composed of farmers' organizations, research institutes/universities, international NGOs and social movements [164]. In Benin and Burkina Faso, the stakeholders involved in the agroecological transition are mainly training and research institutions (IFR), non-governmental 
organizations (NGOs), producer and processor organizations (POs), civil society organizations (CSOs), and consumers (Figure 3) [118,155]. Indeed, smallholder farmers are key to the agroecological transition process [165]. They are grouped into networks that constitute real bridges of collaboration with the other stakeholders of the agroecological transition [42]. Among these organizations, the Peasant Confederation of Faso (French acronym: CPF) and the National Council for Organic farming (French acronym: CNABio) in Burkina Faso are the main ones, while in Benin they are the Federation of farmers' Unions of Benin (French acronym: FUPro Bénin) and the National Association of Women Farmers of Benin (French acronym: ANaF Bénin) [166,167]. The CPF and the FUPro Bénin, together with 11 other national farmers' Organizations, constitute the ROPPA, a structure fully committed to the promotion of agroecology [159].

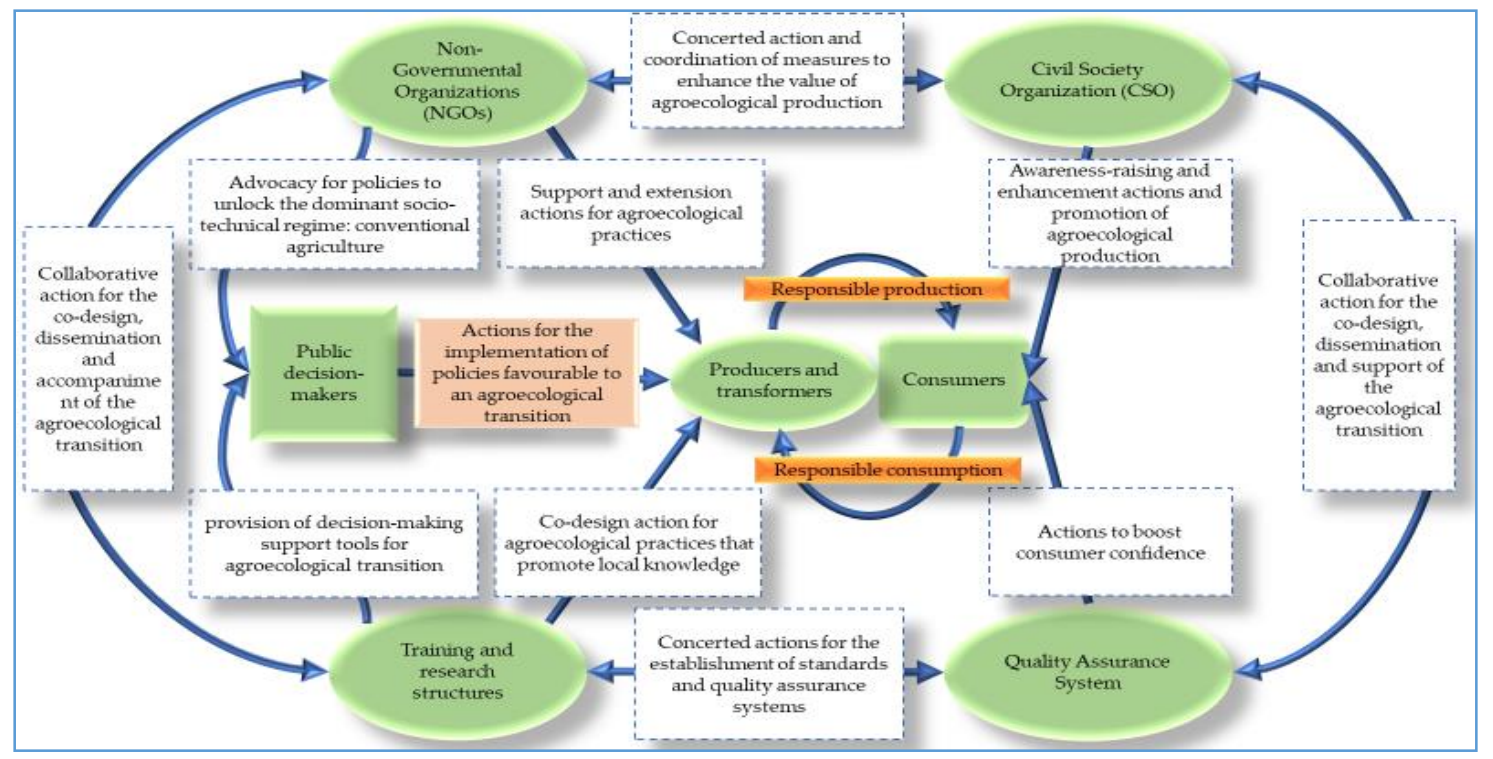

Figure 3. Organizational dynamics of stakeholders in the agroecological transition in Benin and Burkina Faso.

These producer organizations work in synergy with NGOs for the expansion of agroecology in the farming environment. However, the role of NGOs is not limited to the promotion of agroecological practices in the farming environment. As true committed stakeholders, they also contribute to raising consumer awareness and advocate with public decision-makers. They are stakeholders "at the forefront of agroecology" [157]. Among the NGOs campaigning for deep agroecology in Burkina Faso are "Autre Terre", the Association for the Promotion of Local Initiatives (APIL), the Association for Research and Training in Agroecology (ARFA), "SOS faim", and Inter-Réseau Développement Rural. In Benin, we can cite the NGOs Louvain coopération, ECLOSIO, [166,168], farmers' and Non-Governmental Organizations that constitute the "field stakeholders" of the agroecological transition. They are accompanied in this dynamic by training and research institutes that actively contribute to the co-design and dissemination of agroecological practices adapted to the farmers' environment [67]. In addition to these stakeholders, CSOs also play a role in raising awareness and promoting agroecological products among consumers. In Burkina Faso, these are mainly the Citizen's Collective for Agroecology and the fight against GMOs (French acronym: CCAE) and the West African Farmers' Seeds Committee (French acronym: COASP/Burkina) [69]. In Benin, we can cite the Agroecological Federation of Benin (French acronym: FAEB), the Association for the Maintenance of Peasant Agriculture in Benin (French acronym: AMAP) [106]. Moreover, in Burkina Faso, agroecology benefits from the vast network of organic farming stakeholders, which is one of the most developed in the sub-region [155]. Even though agroecology and organic farming most often maintain relations that 
are "neither inclusive nor exclusive" [169], the case of Burkina Faso seems to show a synergy between practices related to these two concepts [170].

However, in both Benin and Burkina Faso, the lack of a consensual definition of the concept of agroecology and its content remains the major challenge for better synergy of action at the level of the stakeholders [69]. Nevertheless, this consensual definition should integrate the diversity of the sectors in order to consider their specificities [42]. The stakeholders are also still confronted with the locking-in of the dominant sociotechnical system of conventional agriculture [27]. However, given the commitment of stakeholders and the convincing results observed at local scales, the main objective remains the scaling up of agroecological practices $[3,25,125,156,171]$.

\subsubsection{Farmers' Perceptions and Adoption of Agroecological Practices}

Agroecology is a production method that puts the producer at the center of his farm management by considering the diversity of situations (e.g., soils, climate, farm structures, local resources) [172]. Agroecological practices can thus be assimilated to "initiatives of diverse and varied forms, taken by agricultural communities living in different countries and contexts" [27]. They reflect a vision of agriculture as part of a new approach to innovation that directly involves the stakeholders concerned in the innovation process, while mobilizing local, traditional, or expert knowledge and the most advanced scientific knowledge in order to optimize their synergies [172]. For this, the inclusion of farmers is central [163]. However, the acceptance of innovations remains a complex and multidimensional notion influenced by a variety of stakeholders, both at the organizational and individual levels [173]. Based on the principle that family farming, particularly in West Africa, can be defined as an organization of lifestyles and production characterized by close links between social and economic activities and family structures $[8,174]$, farmers' decisions are explained by the objectives they pursue and the means at their disposal $[3,175]$. In addition to the specificities of their agroecosystems, farmers integrate the repercussions of their adoption decisions on the social activities and structural organization of the family into their decision-making processes. Life trajectory and behavioral parameters are all determining stakeholders in the adoption of agroecological practices [176,177]. Moreover, agroecological initiatives abound in West Africa $[2,3,25,39,125]$. Seven main categories of agroecological practices have been identified in Burkina Faso and Benin (Table 2).

Table 2. Agroecological clusters and practices with useful references.

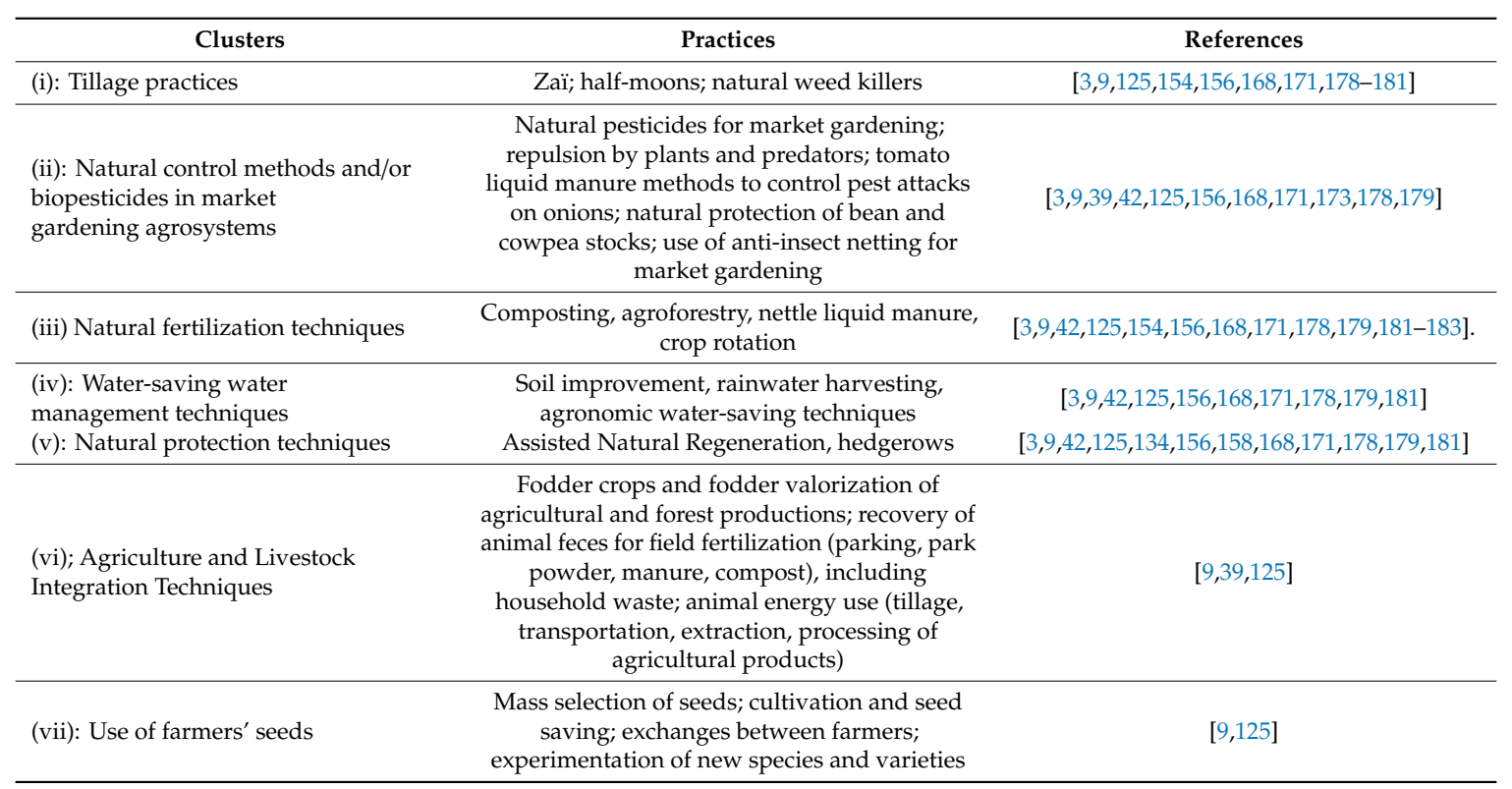


Many of these initiatives are disseminated following a process of co-construction, particularly in pilot farms, before they are appropriated by farmers [118]. In addition, there is a rather unique innovation in Burkina Faso that combines land management and soil fertility improvement: the Sahelian bocage. "The bocage perimeter (wégoubri) is a land consolidation process, at the request of the owners of a site who form a land group in order to fix the plot of land and thereby bring about environmental improvements" [184]. Although agroecological initiatives abound, they often struggle to change scale, particularly through a phenomenon of mass adoption at the producer level [23,42-44]. The most common reasons given for this state of affairs are the arduousness of the work, the lack of commercial outlets for agroecological production, the non-availability, efficiency, and cost of organic inputs, high production costs due to the additional labor involved in mechanizing certain work at the plot level, the non-availability of certain resources such as straw at the terroir level, etc. $[42,69,185]$. It is therefore necessary to intensify collaborative work with farmers in order to better integrate their concerns, but also their knowledge. [3,41,186].

The example of the lack of adoption of conservation agriculture in sub-Saharan Africa illustrates this reality. Considered as one of the best sustainable practices for annual crops by many researchers because of its technical-environmental performance (improvement of soil fertility status, biodiversity, and sustainability of systems), it does not respond to the immediate concerns of farmers who focus on short-term technical-economic effects and results [23,187]. As a result, most recent international projects nowadays have a strong capacity building component and recommend a knowledge management system. However, if farmer knowledge is emphasized in the agroecological approach, it is necessary to avoid idealizing farmers because they are not omniscient and do not know everything. Their knowledge must be combined with scientific knowledge related to the ecosystem in order to build a constant exchange between scientific and local knowledge [163]. Moreover, the political orientation of agriculture in the region transcends the decision-making sphere to affect farmers' perceptions. Despite the health, environmental and social benefits of agroecological practices, they tend to be compared to the Green Revolution methods (with more or rapid results) promoted by extension agents and other development stakeholders in favor of these types of practices. Therefore, it is less necessary to deconstruct the beliefs and perceptions regarding the ineffectiveness of agroecological practices in the farming environment [188]. This requires the extension of adapted agroecological practices that allow farmers, especially the poorest, to maintain a balance between needs and benefits in the short and long term. In this regard, one of the key lessons learnt from the implementation of the Capacity Development for Agricultural Innovation system (CDAIS) project in Burkina Faso is that development stakeholders need a better understanding of innovation processes and the factors that lead to innovation. They must also seek concrete solutions and identify priority interventions and develop strategies that will then spread these successes [189].

\subsection{Some Cross-Cutting Considerations: Agroecology, Gender; Land Tenure; Market Opportunities}

\subsubsection{The Land Question: A Fundamental Prerequisite}

Land is a major factor that is indispensable to the activities of farmers [14]. The land status of farmers can be a determining factor in their decision to adopt agroecological practices. They are considered as indicators of the risk incurred by farmers [163]. Indeed, some agroecological practices can generate significant investments at the plot level in terms of management of working time and the physical environment, while their benefits are deployed over the long term [163,185]. Securing land tenure on farms, therefore, appears to be a prerequisite for any investment by farmers in agroecology $[3,42]$. Given that the benefits of agroecology are long-term, strengthening it goes together with an equitable distribution of land and strengthening of farmers' land rights. Indeed, a lack or poor access to land, with the permanent risk of eventual withdrawal, negatively influences the producer's decision to adopt and invest in agroecological practices [163]. With this in mind, Burkina Faso and Benin have recognized customary rights and are implementing the necessary reforms [100]. These countries have 
relatively satisfactory levels of land availability. Benin accounts for barely $40 \%$ of the exploitable agricultural area, compared to $46 \%$ in Burkina Faso [111,116]. However, the problem of access is very acute in these countries. In Burkina Faso, land management is governed by several laws and policy documents [111]. Among these documents, we can mainly cite the national policy document on land tenure security in rural areas (PNSFMR) adopted in 2007, which aims to ensure equitable access to land for all rural stakeholders, the guarantee of their investments and the effective management of land disputes in order to promote productive and sustainable agriculture [190]. This policy was supplemented by the Agrarian and Land Reorganization (RAF), which was adopted in 2012 [100].

As in Burkina Faso, Benin's land tenure system is still marked by a dualism characterized by the coexistence of a modern land tenure system and a more predominant customary law system. This dualism does not provide a solution to the problems of land tenure insecurity faced by farmers and is a major handicap to agricultural intensification [117]. Thus, despite this political will, the various land tenure reforms seem to have failed to provide solutions to the poor access of a certain category of citizens who are still struggling to gain access to land resources [191]. Indeed, the main mode of access to cultivable land in the country remains inheritance. This state of affairs creates frustrations and conflicts of interest in rural areas because of the inescapable nature of the production factor "land". Women are particularly disadvantaged in this system [69]. For example, female heads of households have an average of 0.25 ha of land for their farms compared to 2.5 ha for men [111]. Nevertheless, the government is still making efforts to improve women's access to land, and women are often the ones who have a particular interest in agroecology and its role in nurturing and protecting the land [163]. In Burkina Faso, for example, this has resulted in the implementation of a law devoting 30\% of developed perimeters to women [192]. In addition to access by inheritance, other forms of access to land are donations, rental, lease, bequests, loans, and purchases, but purchase remains one of the most secure means of access to land [193]. In Benin, the government is working within the law No. 2013-01 of 14 August 2013 on the land and state land code to recognize the right of use, property titles, secure use in shared spaces and the transmission of heritage [58].

\subsubsection{The Gender Issue: The Crucial Role of Youths and Women}

Gender is a major aspect of the agroecological transition in West Africa. Indeed, more than half of the region's agricultural workers are women [108]. They are mainly involved in the production, but also have a considerable role in the processing and marketing of agricultural products [108]. They cultivate as much or more than men [43]. They, therefore, play an important role in the food security of farms and in the process of transition of farms from conventional to agroecological systems [2,182]. They are also known for their innovative capacity and are considered as reservoirs of traditional knowledge for the cultivation, maintenance and use of traditional varieties $[180,194]$. However, when they are not simply seen as valid arms of the family farm in the agricultural production sphere, they are unfortunately restricted to the least fertile land, in the most degraded areas and on unprofitable land $[163,195]$. This discrimination is not limited to the sphere of agricultural production but often extends to the processing chain. They are predominant in the agri-food industries, where they generally occupy the links in the chain that require relatively unqualified work and benefit from temporary contracts [108]. However, instead of feeling self-pity, women are developing initiatives in the production, distribution and local consumption of agroecological products [196,197].

In Burkina Faso, the network of shea butter producers in the Hauts-Bassins and Cascades regions (French acronym: RPBHC) is an example of successful women's agroecological initiatives. It is involved in the exploitation and protection of forest parks for the production of shea butter with 10,500 members, of whom $97 \%$ are women, from 255 groups and associations in six provinces of the country [171]. Similarly, in the central part of the country, since 2008 the NGOs APIL and "SOS Faim" have implemented a market gardening program in agroecology on six irrigated perimeters covering a total area of 71.5 hectares, $59 \%$ of which are managed by women. In about 10 years of operation, this program has contributed to the improvement of the income of the members of the group with 
XOF 396,333,750 turnover, or the equivalent of $€ 604,207$ during the same period [168]. Still in the same dynamic, a network of farmers was created in Togo and Benin with the support of the Christian Service in Support of Rural Animation (French acronym: SECAAR). With agroecological practices, the predominantly female beneficiaries were able to increase their cereal yields by $140 \%$ [183]. However, if women are in favor of adopting agroecological practices, it is important to be aware of the impact of the choices made on the burden and arduousness of women's work, particularly in the sphere of family production [163]. In addition to their participation in agroecological production, women actively participate in the distribution of agroecological products in Benin and Burkina Faso [198].

Apart of women, young people are also strategic stakeholders that should be considered in the agroecological transition process because they not only play an important role on farms but also represent the future of agriculture. Indeed, Burkina Faso and Benin are countries characterized by the extreme youthfulness of their population, a third of whom are under the age of 24 years old [199]. In the family farming systems that represent the majority of farms in these countries, young people, and women, are most often at the forefront of agricultural activities. It is therefore important to stimulate their enthusiasm for agroecology. However, this requires a certain number of prerequisites. Indeed, it is important to focus on training because rural youth, most of whom grew up in the era of conventional agriculture, need training in sustainable agricultural practices. Such training may be particularly necessary to fill the gap created by the formal academic training system [200]. In addition, there is a need to strengthen intergenerational learning for the transmission of knowledge within farms [201]. In this regard, the experience of the intergenerational agroecological schools developed in Bolivia, which consists of associating, in the same training process, members of different ages and sexes from the same family, is a promising alternative to be explored [201]. However, while training is an important aspect of getting young people interested in agroecology, it is not enough and must be accompanied by a set of institutional and political measures, such as access to credit, agricultural inputs, especially land and access to the market [200].

4.3.3. Promoting Agroecological Production: The Role of the Consumer and the Path of Territorialized Food Systems

The economic valorization of agroecological production remains a central issue in the adoption and dissemination of agroecological practices in the farming environment [39]. In other words, "There is no point in producing agroecological foodstuffs if farmers cannot sell them at remunerative prices ..." " [44]. This assertion reflects this reality and clearly reflects the farmers' point of view on the subject. On the basis of this observation, the stakeholders in the transition are developing initiatives to promote local consumption $[39,198]$. Moreover, the development of cities and the urban market in West Africa is a major asset for the development of local consumption and the promotion of agroecological products in particular. In this region, apart from $50 \%$ of household budgets devoted to food, imports represent $20 \%$ of the food supply [202]. Moreover, there is a growing demand for healthy food products among the population, which represents a market opportunity for agroecological production [173]. However, while the poor, who represent more than $43 \%$ (below the poverty line) of the region's population, have a high share of the food budget, their procurement power remains low [121]. This often forces them to buy the cheapest and lowest quality food. However, the promotion of agroecological products refers to a responsible consumer as defined by Calame [50] in his definition of deep agroecology. It requires consumers to act as agents of change in the food system by promoting responsible consumption and deploying innovative alliances [170]. This makes sense in the assertion that "Eating is probably the most common political act we take in our lives. Indeed, what we eat and how we eat determines everything in our present existence and even our future" [198].

In Burkina Faso and Benin, several initiatives aimed to facilitate the flow of agroecological production have been implemented. However, although they all aim to promote the marketing of agroecological production, these initiatives differ in their approaches. In Benin they respond to the principle of "Local and Solidarity Partnerships for Agroecology (PLSA)" [198]. This short marketing 
circuit is based on a reciprocal commitment between organic farmers and consumers formalized by a renewable contract [196]. Among these initiatives are the Association for the Maintenance of Peasant Agriculture in Benin (French acronym: AMAP-Benin), the "Jardin de Marlène", "JINUKUN", the volunteers of the University of Abomey Calavi (UAC), also known as "AVENTIS", and finally, the market gardeners of Atacora-Donga and Mono-Couffo [198]. In Burkina Faso, on the other hand, it is the Participatory Guarantee System (French: Système Participatif de Garantie-SPG) that is frequently encountered [197]. These are alternative mechanisms to certify products intended for the local market [151]. Differently from the PLSA, production is necessarily certified. This participatory guarantee system is complemented by an embryonic PLSA movement. These include the Bioprotect baskets of the economic interest group Bioprotect, the solidarity supply groups (GAS) of the Napoko farm (Loumbila) and finally the organic baskets of the association "La saisonnière" [198] and the Beo-Neere association. In Ouagadougou, several local markets have emerged in recent years thanks to all these stakeholders who are increasingly organized to meet the needs of consumers at all times of the year.

These initiatives are part of a dynamic of "territorialized food system in the sense that it promotes local production in a relatively short distribution circuit [202]. These approaches enable the food demand to be reoriented towards a more abundant and varied local supply of more easily verifiable quality [203]. In Burkina Faso and Benin, they constitute promising approaches that should be explored for a better valorization of agroecological production. Indeed, a sustainable food system implies the development of marketing channels giving priority to local markets while guaranteeing self-consumption, nutrition, and farmers' incomes [163]. Today, territorialized food systems are bridges to the food future of West Africa [202]. This is imperative because their high food imports will constitute a growing budgetary burden and will very quickly become unbearable for the continent [202]. Concerning the issue of low-income households that may encounter difficulties in gaining economic access to agroecological products, solutions based on the concept of the social and solidarity economy could provide a solution [44].

\section{Scaling Up the Agroecological Transition}

\subsection{Farm Transition: A Systemic Process}

Family farms in West Africa are particularly well suited to the development of agroecology. Indeed, they are places for knowledge exchange in which the intergenerational transmission of values related to agriculture takes place [2]. They can thus contribute to the sustainability of agroecological practices. The transition of farms from conventional production methods to agroecological methods is a long process that requires the contribution of several factors [201,204]. Based on natural resources and local ecosystem services, the agroecological transition of the farm necessarily involves local innovation systems of farmers who should, however, extend their local knowledge thanks to scientific knowledge [2]. To do this, the producer should mobilize and develop his learning capacities with regard to poorly known practices that break with the dominant regime $[67,205]$. The agroecological transition of the farm must also be coupled with concomitant changes in the entire production system, or even the agrarian system [3]. In this dynamic, agricultural practices must be reasoned and based on an intimate understanding of the functioning of the agroecosystem [172]. In the specific cases of Burkina Faso and Benin, the integration of polyculture and livestock farming systems could facilitate the transition process of farms. This enables the optimization of energy and material flows between the subsystems of the farms. Moreover, the adoption of agroecological production methods by the producer can be followed by the transition period, which corresponds to the time needed for the farm to recover its ecological and natural balance [69].

Depending on the history (level of previous use of fertilizers, pesticides, etc.) of the farm on which the producer initiates agroecological practices and the intensity of the new practices applied by the producer, the transition period can be an obstacle that may discourage the producer $[163,201]$. 
During this period he may be confronted with the phenomenon of lower yields and the more the farm was affected, the longer the transition period is $[69,206]$. During this period, external inputs are needed to bring the soil back to life, but this can be costly for the producer [201]. Thus, the latter may experience a yield decline coupled with an increase in expenses during this critical phase [204], when they are most often faced with the need to respond quickly to their food and financial needs. It is therefore necessary that the practices adopted meet both their short-term objectives (food, income generation) and their long-term objectives (improving fertility) [163]. However, it should be underlined that the transition period of the plot does not necessarily rhyme with a drop in productivity. In Burkina Faso, for example, the application of the Zaï practice or the half-moon coupled with compost can double or even triple the yield from the first year on the plot scale [181]. In view of the stakes of the transition period for the producer, it is therefore necessary that they are accompanied during this period [201,204]. This support should, however, consider the typology of the farms to be more effective [110]. In Burkina Faso and Benin, a ranking of the difficulties encountered in their transition processes has shown that the lack of institutional support is the first challenge faced by farmers, while within the plots in transition, pests and plant pathological diseases have been the first risk factor [198].

However, family farming, especially when practiced in rain-deficient areas, is particularly vulnerable [180]. In Northern Burkina Faso, for example, farmers are in a situation of almost permanent food insecurity and the low level of their income makes it difficult to invest in farms [180]. Support for farmers in their transition process is essentially based on NGOs and research and training institutes through initiatives such as farm schools, which are forums for meetings and exchanges of experiences [118,204]. Thus, the corollary of this lack of institutional support is the difficult technical conversion of farmers [198]. Another difficulty in the agroecological transition of farms in Burkina Faso and Benin remains the use of chemical inputs, often in an uncontrolled manner, particularly in cotton-growing areas $[148,149]$. This situation could lengthen the transition period for farms wishing to take the agroecological path in these zones. Nevertheless, it should be noted that local initiatives to accompany the agroecological transition are increasingly being developed by private sector stakeholders. Most of them are characterized by the provision of bio-inputs (e.g., fertilizers, biopesticides), equipment adapted to agroecology and organic farming. Among these initiatives are the Biolife startup in Benin and the Bioprotect economic interest group (GIE) in Burkina Faso [155]. This could provide an alternative with regard to chemical inputs for farmers who wish to make an agroecological transition on their farms. Moreover, the example of the co-construction work on innovative polyculture systems since 2005 in the west of Burkina Faso, one of the country's main cotton-growing areas, has shown the capacity of these stakeholders to engage in an agroecological transition dynamic [39].

\subsection{From Farm to Territory: A Non-Linear Transition}

The adoption of agroecological practices is easier when it is collective, because it is slower and more difficult to manage when it is individual [49]. Indeed, the mobilization of ecosystem services on which the implementation of agroecology depends generally goes beyond the scale of the cultivated plot and is at higher scales such as the farm, the landscape, the watershed, and more generally the food system $[2,186]$. Therefore, in order to guarantee its sustainability and development on a territorial scale, agroecology should be part of a global vision of territorial issues [25]. It is therefore necessary to think globally about the conditions of the ecological transition [3]. This requires farmers to coordinate production strategies, both in their own area and on their periphery [2]. Moreover, considering that agroecology must respond to the challenges of territories, the ambitions of moving to the scale of agroecology in a territory should essentially be accompanied by a diagnostic phase in order to evaluate the potentialities and perspectives best suited to the context [25]. Moreover, the agroecological transition cannot be limited to the sum of individual transitions on innovative farms [39]. Beyond production, the amplification of agroecology must be considered as a transformation of food systems, rather than a pure dissemination of a set of food production techniques [207]. "Agroecology is not just a catalogue 
of good agricultural practices, no more than it is intended to remain confined to a "niche market" [22]. This assertion by Alternatives Sud clearly reflects this vision of the agroecological transition. In order to optimize the agroecological transition process at the territorial level, legal, and regulatory regimes must be implemented to ensure a transformative change towards sustainable agricultural and food systems based as much as possible on agroecology [170]. Furthermore, the transition process should ensure that the stakeholders who produce, distribute, and consume food are at the center of decision-making on food systems and policies [2].

In Burkina Faso and Benin, the agroecological transition is increasingly moving beyond the context of ecological production innovation networks to include initiatives to market agroecological production $[2,3,25,39,125,198]$. In this context, certifications, particularly participatory guarantee systems (SPG), represent very interesting approaches to enhance agroecological production for a greater number of consumers [163]. However, these hopeful short circuits need to be improved. From the supply point of view, they tend to focus mainly on fruit and vegetables and very rarely address the issue of cereals, which nevertheless remain the basis of the diet of the populations in these countries. As far as supply points are concerned, they remain largely unknown to the majority of the population. Nevertheless, the SPGs can help territorial food systems to take root, which would guarantee a scaling up of agroecology at the territorial level. They allow an "articulation between production and food, considered independently in many cases" [172]. This articulation at the territorial level could correspond to the niche mentioned in the multi-level perspective of the sociotechnical transition. The territorial limits of this niche may correspond, depending on the relevance, to national administrative limits or agroecological zoning in Burkina Faso and Benin. This would enable the various stakeholders involved to combine their efforts to have a better impact on the territories concerned. Moreover, the "territorial mechanisms" approach can be used to amplify the transition of the territories (Figure 4). Designed to ensure an essential regulatory role among local stakeholders, they are real levers for amplifying the agroecological transition [39]. Considering these conditions, beyond the individual transitions of innovative farms, the amplification of the agroecological transition could also be apprehended through the efficiency of territorial stakeholders in articulating production and consumption through relationships based on a common ideal: healthy eating while keeping the impact of the food system on the territory's resources at its lowest possible level.

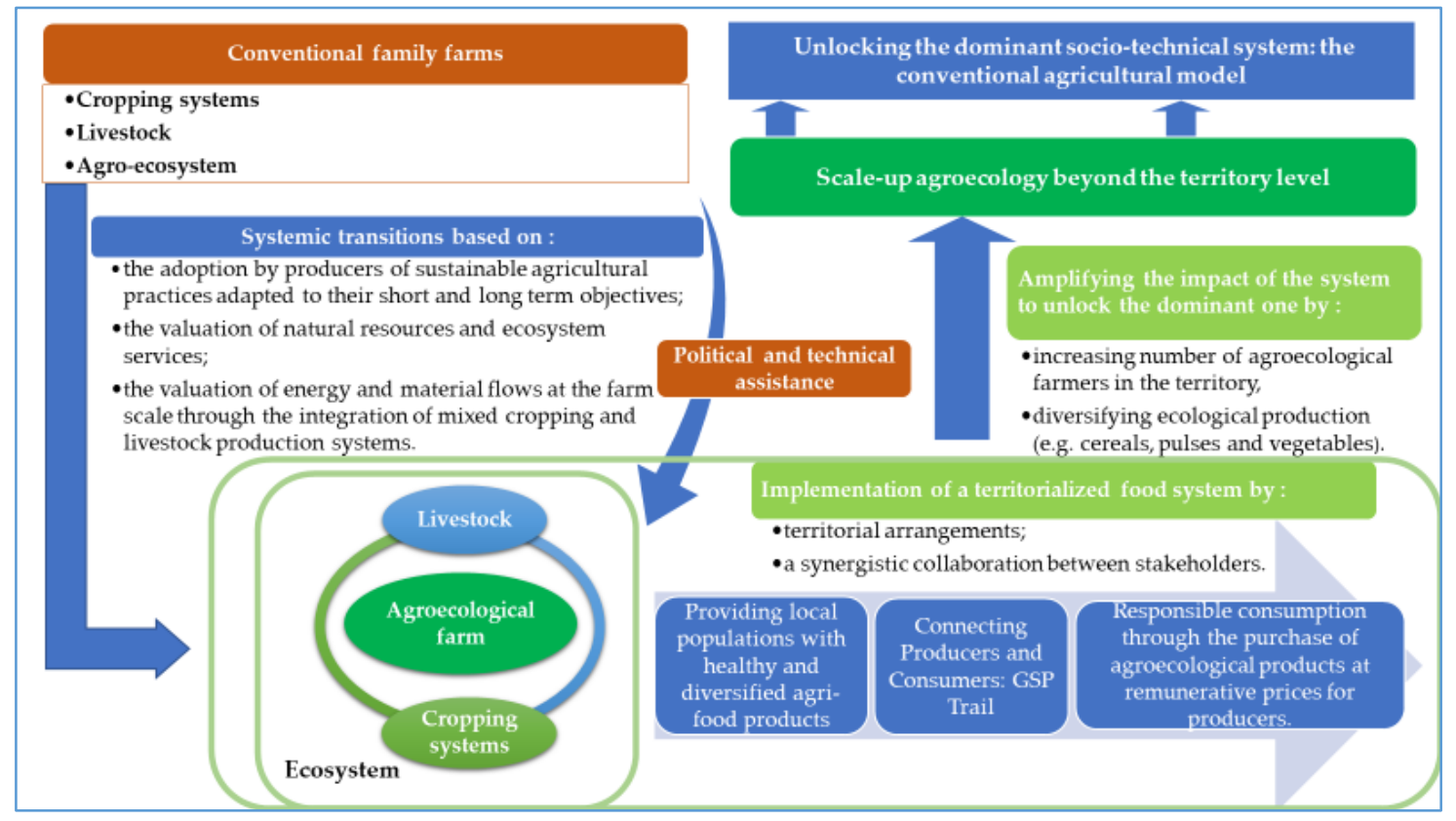

Figure 4. Schematic pathway of the transition process. 


\section{Conclusions}

The objective of this review was to establish a diagnosis of the individual, social, economic, institutional, and political factors that influence agroecological production in Burkina Faso and Benin in order to propose avenues for a change of scale in agroecology. For this purpose, the multi-level perspective of ecological transition has been used. This analysis shows that nowadays, agroecology is a holistic concept that corresponds to a set of practices, a science, and a social movement. In its deep acceptance, it can be seen as a "profound reform from farm to fork" of the food system. At the end of this analysis, it is important to remember that there is no such thing as an agroecological transition, but rather agroecological transitions that differ according to the environmental, cultural, political, and socioeconomic realities of the territories in question.

In West Africa, the agroecological transition involves several issues, including food sovereignty and the protection of natural resources. The agrarian context of the region remains marked by the agricultural model based on productivist methods. In Burkina Faso and Benin in particular, farms are family-run, mostly poorly mechanized, and practice rain-fed subsistence agriculture with low-income levels. This situation contributes to making them particularly vulnerable and rain-fed to the risk of technological innovation in general and agroecological practices in particular. In addition, this agrarian context remains marked by the omnipresence of cotton, a crop known for its excessive use of chemical inputs and the environmental disasters it causes. However, organic cotton production is increasingly developing in these countries, particularly in Benin. In view of the environmental and health benefits that this alternative offers, the political authorities could seize this opportunity and commit cotton farmers to a more sustainable production, especially since the demand for organic cotton is increasing worldwide. Moreover, in a dynamic of regional integration, national agricultural policies in West Africa are strongly influenced by regional agricultural policies (ECOWAP, PAU) which seem to have put their trust in the green revolution model to solve the challenges facing agriculture in the region. This good orientation is flowing into national agricultural policies and reflects a flagrant lack of institutional support for agroecological initiatives. While in Burkina Faso there is a timid beginning of intentional recognition of agroecology, in Benin advocacy is ongoing.

Despite the lack of institutional support, initiatives in Burkina Faso and Benin are expanding and diversifying, led by non-governmental organizations, civil society organizations, farmers' organizations, and training and research institutions. Beyond these two countries, an important network has been set up in West Africa for the promotion of agroecology. These stakeholders' commitment has led to the establishment of several agroecological initiatives with farmers, who are the stakeholders at the forefront of the agroecological transition. However, agroecological practices are actions that must be sustained over time. Their profitability is often deferred in time, which can severely challenge the will of producers who are, above all, economic agents who live from their activities: Agriculture. However, beyond questions of profitability, agroecology requires a personal commitment of the farmers, stemming, on the one hand, from a philosophy of accountability towards future generations, and, on the other hand, from a perception of the irreplaceable nature of the ecosystem services provided by nature. This is part of the vision of a deep agroecology in the sense that taking into account the needs of future generations without integrating the inalienable nature of natural resources would lead to a weak agroecology position. It took, for example, more than 40 years of hard work by Mr. Yacouba Sawadogo to see his work greening an entire ecosystem and coming under the spotlight. However, if the role of the producer is crucial in the agroecological transition process, it is equally necessary not to put the entire weight of the agroecological transition on their shoulders. It is important that farmers be accompanied in this process by public decision-makers as well as other stakeholders, such as researchers, NGOs, CSOs, etc.

In addition, the agroecological transition raises a number of cross-cutting concerns that are also critical to its success. Indeed, regarding both financial and material investments as well as the delayed nature of agroecology, good land tenure security remains necessary to convince the producer. Moreover, the agroecological transition cannot put gender aspects, particularly those 
of young people and women, in second place. Present in all stages of the food production and distribution chain, women are also known for their ability to support innovation. In addition to land and gender problems, the economical valorization of agroecological production remains one of the major problems agroecological transition stakeholders have to solve. Moreover, while young people are key stakeholders in today's agroecological transition, they are also, and above all, the future of agroecology in Burkina Faso and Benin. Their perceptions and apprehensions must therefore be the subject of particular attention by the stakeholders of the agroecological transition in order to ensure their adherence to the process.

Two levels of agroecological transition analysis are necessary to better understand the phenomenon of amplification of the agroecological transition in a territory. The first is the farm transition, which begins with the producer's decision to begin agroecological production and continues until the farm reaches its ecological equilibrium. This period represents a critical phase for farmers and requires technical and institutional support. The second level of analysis of the agroecological transition remains the territory. However, if the territory can be assimilated to a sum of farms, the scaling of the agroecological transition of the territory is not the sum of the individual farm transitions within the territory. It must be seen as a transformation of the food system rather than simple dissemination of ecological farms at the scale of the territory. This is the reason that it involves a greater number of stakeholders. Territorialized food systems enable this vision to be operationalized. Several efforts have been made in this sense in Burkina Faso and Benin through participatory guarantee systems, which are potential approaches for the transition to the agroecological scale in these countries. That way, the multiplication of territorialized food systems in Burkina Faso and Benin as well as their efficiency can be indicators of the amplification of the agroecological transition at the scale of these countries.

Author Contributions: P.K.T., A.K.N.A., M.K., M.-P.K., and E.G.A.-D. conceived the review; P.K.T. and C.L. performed the literature research; A.K.N.A., M.K., M.-P.K., and E.G.A.-D. analyzed the scientific rigor; E.G.A.-D. coordinated the structure and scope of the topic; P.K.T. wrote the paper. All authors have read and agreed to the published version of the manuscript.

Funding: This research was funded by Académie de Recherche et d'Enseignement Supérieur (ARES) from Belgium.

Conflicts of Interest: The authors declare no conflict of interest.

\section{References}

1. ONU. Report of the World Commission on Environment and Development Our Common Future. Our Common Future 1987. [CrossRef]

2. FAO. Rapport des Rencontres Régionales sur L'agroécologie en Afrique Sub-Saharienne Dakar, Sénégal, 5-6 Novembre 2015; FAO: Rome, Italy, 2017; 74p.

3. Levard, L.; Mathieu, B. Agroécologie; capitalisation d'expériences en Afrique de l'Ouest Facteurs favorables et limitants au développement de pratiques agroécologiques. Évaluation des Effets Socio-Économiques et Agro-Environnementaux 2018. 82p.

4. CEDEAO. L'agriculture et L'alimentation en Afrique de l'Ouest: Mutations, Performances et Politiques Agricoles; CEDEAO: Nigeria, Africa, 2015; Volume 138.

5. FAO, OMS, UNICEF, PAM, et FIDA. L'état de la Sécurité Alimentaire et de la Nutrition Dans le Monde: Se Prémunir Contre Les Ralentissements et Les Fléchissements Économiques. Available online: http: //www.fao.org/3/ca5162fr/ca5162fr.pdf (accessed on 5 May 2020).

6. OECD/FAO. Agriculture in Sub-Saharan Africa: Prospects and challenges. OECD Publ. Paris. 2016. 181p.

7. Pison, G. Tous les pays du monde (2019). Popul. et Sociétés Numéro 569 Sept. 2019, 2019. 8p. [CrossRef]

8. Courade, G.; Devèze, J.-C. Des agricultures africaines face à de difficiles transitions cairn info, Afrique contemporaine. Afr. Contemp. 2006, 217, 21-41.

9. Bance, S. Caractérisation des Dispositifs D'accompagnement des Exploitations Agricoles Familiales vers L'intensification Durable au Burkina Faso; Université de Ouagadougou: Ouagadougou, Burkina Faso, 2013. 
10. Hollinger, F.; et Staatz, J.M. Croissance Agricole en Afrique de l'Ouest Facteurs Déterminants de Marché et de Politique; Banque africaine du développement et Organisation des nations unies pour l'alimentation et l'agriculture: Rome, Italy, 2015; 453p.

11. FAO et ITPS. État des Ressources en sols du Monde—Résumé Technique Organisation des Nations Unies Pour L'alimentation et L'agriculture et Groupe Technique Intergouvernemental sur les sols; FAO: Rome, Italy, 2016; 92p.

12. Roose, E. Dégradation des terres et développement en Afrique de l' Ouest. Bull. Rech. Agron. Gembloux 1985, 20, 505-537.

13. Kanouté, A.C.; Diop, N.M.; Diaw, M.; et Diallo, C.H. Le Village où on N'entend Plus le Pilon. Accaparement des Terres en Afrique de l'Ouest. Exporter ou Nourrir les Populations. Impact sur les Consommateurs Ruraux. Available online: http://www.hubrural.org/IMG/pdf/accaparement_des_terres_rapport_diokoul_1sur2.pdf (accessed on 28 April 2020).

14. GRAIN. Accaparement des Terres et Souveraineté Alimentaire en Afrique de l'Ouest et du Centre; Grain: Barcelona, Espagne, 2012; 10p.

15. Halewood, M.; Baidu-Forson, J.J.; Clancy, E.; et Vodouhe, R.S. La Coopération Pour le Meilleur Usage Possible des Ressources Phytogénétiques en Afrique de l'Ouest et Centrale: Un Impératif Régional; Biodiversity International and Coraf/Wecard: Rome, Italy, 2014; 96p. [CrossRef]

16. GRAIN. Les rapports de Grain: Une Nouvelle Révolution Verte Pour l'Afrique? Grain: Barcelona, Espagne, 2007; 8p.

17. Beauval, V.; Dufumier, M. Les plantes génétiquement modifiées peuvent-elles nourrir le tiers monde? Rev. Tiers Monde 2006, 188, 739-754. [CrossRef]

18. Patel, R. The Long Green Revolution. J. Peasant Stud. 2013, 40, 1-63. [CrossRef]

19. Vilain, R. La Nouvelle Révolution Verte en Afrique subsaharienne-Partie 1 sur 2. Available online: http://cadtm.org/La-nouvelle-revolution-verte-en-Afrique-subsaharienne-Partie-1-sur-2 (accessed on 20 April 2020).

20. Wu, F.; Butz, W. The future of genetically modified crops: Lessons from the green revolution. Aust. Occup. Ther. J. 2004. 47p.

21. Dasgupta, K. Pas si rose, la Révolution verte! En Inde, la Révolution verte a peut-être enrichi le Pendjab, mais elle ruine les terres et les petits paysans, acculés à s'endetter et à migrer vers les villes. Le Courrier 2001, Janvier 2011, 27-28.

22. Alternative-Sud. Agroécologie: Enjeux et Perspectives; Cetri: Louvain la Neuve, Belgique, 2014; 216p.

23. Dugué, P.; Autfray, P.; Blanchard, M.; Djamen, P.; Dongmo, A.; Girard, P.; Olina, J.-P.; Ouedraogo, S.; Sissoko, F.; Vall, E. L'agroécologie pour l'agriculture familiale dans les pays du Sud: Impasse ou voie d'avenir ? Le cas des zones de savane cotonnière de l'Afrique de l'Ouest et du Centre. in Colloque René Dumont, Paris, 15 et 16 novembre 2012. Atelier 1 Agro-écologie Lagroécologie 2014. 25p.

24. Radja, K.; Schembri, P.; et Bazin, D. Quels enjeux de soutenabilité pour l'agriculture indienne? Économie Rural 2016, 352, 23-39. [CrossRef]

25. Berton, S.; Billaz, R.; Burger, P.; Lebreton, A. Agroécologie, une Transition vers des Modes de vie et de Développement Viables. Paroles D'acteurs; Centre D'actions et de réalisations internationales (Cari): Viol le fort, France, 2013; 96p.

26. Étienne, G. La révolution verte en Asie: Essai de bilan et perspectives. Tiers. Monde. 1987, 28, 909-918. [CrossRef]

27. IPES-Food. De l'Uniformité et la Diversité: Changer de Paradigme Pour Passer de L'agriculture Industrielle à des Systèmes Agroécologiques Diversfés; Ipes-food: Bruxelles, Belgique, 2016; 110p.

28. OCDE/FAO. Perspectives Agricoles de L'OCDE et de la FAO; OECD Publishing: Paris, France, 2014. [CrossRef]

29. Racine, J.-L. Géopolitique de l' agriculture indienne. Hérodote 2015, 156, 29-49. [CrossRef]

30. Service D'entraide et de Liaison (SEL). La Mondialisation et L'agriculture. Available online: http://www. selfrance.org/fileadmin/_migrated/content_uploads/Mondialisation_02.pdf (accessed on 19 April 2020).

31. Mouvement Mondial Pour les Forêts Tropicales (WRM). La Révolution Verte: Des Cultures D'alimentation aux Cultures de Domination. Available online: http://wrm.org.uy/fr/les-articles-du-bulletin-wrm/section1/ la-revolution-verte-des-cultures-dalimentation-aux-cultures-de-domination/ (accessed on 23 May 2020). 
32. BAD. «La Révolution Verte est non Seulement Tout à Fait Possible, Mais Nécessaire et Urgente en Afrique» | Banque Africaine de Développement—Bâtir Aujourd'hui, une Meilleure Afrique Demain. Available online: http://www.afdb.org/fr/news-and-events/how-to-make-the-green-revolution-a-reality-in-africa-17294\#: $\sim\{\}:$ text=unouiferme.-,Larévolutionverteestnonseulementtoutàfaitpossible,nécessaireeturgenteenAfrique. \&text=L $\backslash \mathrm{T} 1 \backslash$ textquoterightAfriquenepeutse, transformant (accessed on 7 May 2020).

33. Raworth, K. La Théorie du Donut: L'économie de Demain en 7 Principes; Plon: Paris, France, 2018; 428p.

34. FAO. La situation mondiale de l'alimentation et de l'agriculture 2019. In Aller Plus Loin Dans la Réduction des Pertes et Gaspillages de Denrées Alimentaires; FAO: Rome, Italy, 2019; 203p. [CrossRef]

35. Alimenterre. Fiche Thématique Agriculture et Forêt Face au Défi du Changement Climatique. Available online: http://www.alimenterre.org/system/files/2018-10/fiche-thematique-climat-201809-hb-fdaft-v2mm.pdf (accessed on 8 May 2020).

36. Altieri, M.A.; Pimbert, M.P. L'Agroécologie: Bases Scientifiques d'une Agriculture Alternative; Debard; Charles Corlet: Normandie, France, 1986; 237p.

37. Francis, C.; Lieblein, G.; Gliessman, S.; Breland, T.A.; Creamer, N.; Harwood, R.; Salomonsson, L.; Helenius, J.; Rickerl, D.; Salvador, R.; et al. Agroecology: The Ecology of Food Systems. J. Sustain. Agric. 2003, 22, $99-118$. [CrossRef]

38. Agrisud. L'agroécologie en Pratiques_GUIDE Édition 2010. Available online: http://www.agrisud.org/wpcontent/uploads/2013/05/Guide_Francais.pdf (accessed on 13 June 2020).

39. Côte, F.-X.; Poirier-Magona, E.; Perret, S.; Rapidel, B.; Roudier, P.; Thirion, T.M.-C. (Eds.) La Transition Agro-Écologique des Agricultures du Sud. La Transition Agro-Écologique des Agricultures du Sud; Éditions Quae: Versailles, France, 2018; 368p. [CrossRef]

40. FAO. Objectifs de Développement Durable, Travaillons Pour Faim Zéro: Le Travail de la Fao au Service de L'agroécologie vers la Réalisation des ODD. Available online: http://www.fao.org/3/19021FR/i9021fr.pdf (accessed on 21 April 2020).

41. Doré, T.; Bellon, S. Les Mondes de l'Agroécologie; Éditions Quae: Versailles, France, 2019; 176p.

42. Inter-réseaux Développement rural (IRDR). Compte rendu de la rencontre sur: Les agriculteurs engagés dans l'agroécologie au Burkina Faso partage d'expériences, défis et perspectives 24-25 Novembre 2015. Cycle Thématique Agroécologie 2015. 6p.

43. AGRIDAPE. Numéro spécial Farming Matters, mars 2018, L'agroécologie, une voie pour atteindre les ODD. Available online: http://www.iedafrique.org/IMG/pdf/agridape_numero_special_fm-fr.pdf (accessed on 8 March 2020).

44. ROPPA et IPES Food. Compte-Rendu Stratégique de la Réunion de Lancement 'Mettre en Lumière des Alternatives Agroécologiques: Un processus Collaboratif de Réflexion et D'engagement en Afrique de l'Ouest'. Available online: http://www.ipes-food.org/_img/upload/files/3AO_-_CR_et_Feuille_de_route_.pdf (accessed on 6 March 2020).

45. Durkheim, É. Éducation et Sociologie; Good Press: Glasgow, UK, 1922.

46. Lampridi, M.G.; Sorensen, C.G.; Bochtis, D. Agricultural sustainability: A review of concepts and methods. Sustainability 2019, 11, 5120. [CrossRef]

47. Velten, S.; Leventon, J.; Jager, N.; Newig, J. What is sustainable agriculture? A systematic review. Sustainability 2015, 7, 7833-7865. [CrossRef]

48. Mendeley. Feed | Mendeley. Available online: http://www.mendeley.com/newsfeed (accessed on 20 May 2020).

49. Trabelsi, M. Comment Mesurer la Performance Agroécologique d'une Exploitation Agricole Pour L'accompagner dans son Processus de Transition? Université Paul Valéry: Montpellier, France, 2018.

50. Calame, M. Comprendre L'Agroécologie. Origines, Principes et Politiques; ECLM: Northampton, UK, 2016.

51. Bensin, B.M. Possibilities for international cooperation in agroecological investigations. Int. Rev. Agr. Mo. Bull. Agr. Sci. Pr. 1930, 21, 277-284.

52. Azzi, G. Agricultural Ecology; Constable: London, UK, 1956; 424p.

53. Klages, K.H.W. Ecological crop geography, Macmillan Company. Am. J. Agric. Econ. 1942, $24,615$.

54. Hanson, H.C. Ecology in agriculture. Ecology 1939, 20, 111-117. [CrossRef]

55. Wezel, A.; Bellon, S.; Dore, T.; Francis, C.; Vallod, D. and David C. Agroecology as a science, a movement and a practice. Sustain. Agric. 2009, 2, 27-43. 
56. Gliessman, S.R.; Garcia, R.E.; Amador, A.M. The ecological basis for the application of traditional agricultural technology in the management of tropical agro-ecosystems*. Agro-Ecosyst. 1981, 7, 173-185. [CrossRef]

57. Altieri, M. Agroecology: The science of sustainable agriculture. Boulder. Westview Press. Part Three Dev. Clim. Rights 1995, 238, 12052-12057.

58. Ministère de l'Agriculture de l'Elevage et de la Pêche du Bénin (MAEP) et Nouveau Partenariat Pour le Développement de l'Afrique (NEPAD). Plan Stratégique de Développement du Secteur Agricole (PSDSA) 2025 et Plan National d'Investissements Agricoles et de Sécurité Alimentaire et Nutritionnelle Pniasan 2017-2021. Available online: http://extwprlegs1.fao.org/docs/pdf/Ben184002.pdf (accessed on 14 May 2020).

59. Norgaard, R.B.; Sustainability and the Economics of Assuring Assets for Future Generations. Policy Research. Available online: http://books.google.com/books?hl=en\&lr=\&id=OKoh0DB2FiAC\&oi=fnd\&pg=PA1\&dq= Sustainability+and+the+Economics+of + Assuring + Assets + for + Future + Generations\&ots=Duab4nsSaB\& sig=ebF49vtwUd6kxkNTnOgzizxM0qk (accessed on 22 May 2020).

60. Buttel, F.H. Environmenatl sociology and the explanation of environmental reform. Organ. Environ. 2003, 16, 306-344. [CrossRef]

61. Allaverdian, C.; Ferrand, P.; Kibler, J.-F.; Reynaud, L. Cadrage: L'agroécologie, un concept pour une diversité d'approches. Juillet 2014, 20, 6-7.

62. Altieri, M.A.; et Toledo, V.M. The agroecological revolution in Latin America: Rescuing nature, ensuring food sovereignty and empowering peasants. J. Peasant Stud. 2011, 38, 587-612. [CrossRef]

63. Leménager, T.; et Ehrenstein, V. Des principes agroécologiques à leur mise en pratique. Quels effets environnementaux en Zambie et quels enseignements pour les bailleurs de fonds? Arman. Colin Rev. Tiers Monde 2016, 3, 65-93. [CrossRef]

64. Altieri, M.A. Agroecology: The science of sustainable agriculture. J. Peasant Stud. 1995, 38.3, 587-612. [CrossRef]

65. Gliessman, S.R. Agroecology: The Ecology of Sustainable Food Systems; CRC Press: Boca Raton, FL, USA, 2007.

66. Claveirole, C. La transition agroécologique: Défis et enjeux. Paris, les éditions des Journaux officiels 2016. 114p.

67. Caquet, T.; Gascuel, C.; Tixier-Boichard, M.; Dedieu, B.; Détang-Dessendre, C.; Dupraz, P.; Faverdin, P.; Hazard, L.; Hinsinger, L.; Lescourret, F.; et al. L'agroécologie: Des Recherches pour la Transition des Filières et des Territoires; Éditions Quæ: Versailles Cedex, France, 2020; 107p. [CrossRef]

68. Boisvert, V.; Carnoye, L.; Petitimbert, R. «La durabilité forte: Enjeux épistémologiques et politiques, de l'économie écologique aux autres sciences sociales»: Entretien avec Valérie Boisvert mené par Leslie Carnoye et Rémi Petitimbert. Développement Durable Territ. 2019, 10, 1-16. [CrossRef]

69. Ouedraogo, F. Analyse de la Durabilité des Exploitations Maraîchères du Burkina Faso: Essai d'une Approche Socio-Écosystémique (cas de la Province du Houet); Université Catholique de Louvain: Ottignies-Louvain-la-Neuve, Belgium, 2019.

70. Landais, E. Agriculture durable: Les fondements par Etienne Landais. Courr. L'environnement l'INRA 1998, 33, 23-39.

71. Theys, J.; Guimont, C. «Nous n'avons jamais été "soutenables": Pourquoi revisiter aujourd'hui la notion de durabilité forte ?». Développement Durable Territ 2019, 10, 1-25. [CrossRef]

72. Vivien, F.-D. Les modèles économiques de soutenabilité et le changement climatique Cairn info, La Découverte. La Découverte Regards Croisés sur L'économie 2009, 6, 75-83. [CrossRef]

73. Pingault, N.; Préault, B. Indicateurs de Développement Durable: Un Outil de Diagnostic et D’aide à la Décision. Notes et études économiques $n^{\circ} 28$ 2007, 43p.

74. Brunel, S. Chapitre V Qu'estce que la durabilité ? In Le Développement Durable; Presses Universitaires de France: Paris, France, 2012; pp. 55-61.

75. Horlings, L.G.; Marsden, T.K. Towards the real green revolution? Exploring the conceptual dimensions of a new ecological modernisation of agriculture that could "feed the world." Glob. Environ. Chang. 2011, 21, $441-452$.

76. Duru, M.; Farès, M.; Therond, O. Un cadre conceptuel pour penser maintenant (et organiser demain) la transition agroécologique de l'agriculture dans les territoires. Cah. Agric. 2014, 23, 84-95.

77. FAO. Les 10 Éléments de L'agroécologie. Guider la Transition vers des Systèmes Alimentaires et Agricoles Durables. Available online: http://www.fao.org/3/i9037fr/I9037FR.pdf (accessed on 18 June 2020). 
78. Maes, S. Agroécologie et Souveraineté Alimentaire: Des concepts Réellement Intelligents Face Aux Défis à Venir. Available online: http://www.oxfammagasinsdumonde.be/blog/2015/12/13/agroecologie-souverainetealimentaire-des-concepts-reellement-intelligents-face-aux-defis-a-venir/\#.X0DgUuhKjIU (accessed on 15 May 2020).

79. Nyeleni. Forum pour la Souveraineté Alimentaire Sélingué, Mali 23-27 février 2007. Available online: https://nyeleni.org/DOWNLOADS/Nyelni_FR.pdf (accessed on 18 August 2020).

80. Eclosio. Semences Paysannes: À la Racine de Notre Souveraineté Alimentaire. Available online: http://www.eclosio.ong/wp-content/uploads/2018/09/semences-paysannes-a-la-racide-de-notresouverainete-alimentaire.pdf (accessed on 16 August 2020).

81. Levard, L.; Bertrand, M.; et Masse, P. Mémento Pour L 'Évaluation De L' Agroécologie. In Méthode Pour Évaluer ses Effets et les Conditions de son Développement Mars 2019; GTAE-AgroParisTech-CIRAD-IRD: Nogent-sur-Marnen, France, 2019; 135p.

82. Gross, B. Agroécologie du Développement Maraicher au Burkina Faso Réorganisation Spatiales, Transformation Socioéconomiques et Enjeux de Développement; Université de Lausanne: Lausanne, Switzerland, 2018.

83. Clark, W.; Kates, R.; members of the B. on Screw Down Non-Return. Our Common Journey: A Transition Toward Sustainability; National Academies Press: Washington, DC, USA, 1999.

84. Markard, J.; Raven, R.; Truffer, B. Sustainability transitions: An emerging field of research and its prospects. Res. Policy 2012, 41, 955-967. [CrossRef]

85. Hoogma, R.; Kemp, R.; Schot, J.; et Truffer, B. Experimenting for sustainable transport: The approach of strategic niche management. Exp. Sustain. Transp. Approach Strateg. Niche Manag. 2005. [CrossRef]

86. Kemp, R.; Loorbach, D.; Rotmans, J. Transition management as a model for managing processes of co-evolution towards sustainable development. Int. J. Sustain. Dev. World Ecol. 2007, 14, 78-91. [CrossRef]

87. Rotmans, J.; Fischer-Kowalski, M. Conceptualizing, observing and comparing socioecological transitions. Socioecol. Trans. Glob. Chang. Trajectories Soc. Metab. L. Use 2009, 14, 1-30.

88. Carlsson, B.; Stankiewicz, R. On the nature, function and composition of technological systems. J. Evol. Econ. 1991, 1, 93-118. [CrossRef]

89. Jacobsson, S.; Bergek, A. Innovation system analyses and sustainability transitions: Contributions and suggestions for research. Environ. Innov. Soc. Transit. 2011, 1, 41-57. [CrossRef]

90. Geels, F.W. Technological transitions as evolutionary reconfiguration processes: A multi-level perspective and a case-study. Res. Policy 2002, 31, 1257-1274. [CrossRef]

91. Geels, F.W.; Schot, J. Typology of sociotechnical transition pathways. Res. Policy 2007, 36, 399-417. [CrossRef]

92. Grin, J.; Rotmans, J.; Schot, J.W. Transitions to sustainable development: New directions in the study of long term transformative change. Res. Policy 2010, 39, 435-448.

93. Meynard, J.M.; Messéan, A.; Charlier, A.; Farès, M.; Le Bail, M.; et Magrini, M.B. Freins et leviers à la Diversification des Cultures. Etude au Niveau des Exploitations Agricoles et des Filières. Available online: http://www6.paris.inrae.fr/depe/content/download/3706/35570/version/1/file/Rapport+ final+Etude+Diversification.pdf (accessed on 2 June 2020).

94. Geels, F.W. From sectoral systems of innovation to socio-technical systems: Insights about dynamics and change from sociology and institutional theory. Res. Policy 2004, 33, 897-920. [CrossRef]

95. Vanloqueren, G.; et Baret, P.V. How agricultural research systems shape a technological regime that develops genetic engineering but locks out agroecological innovations. Res. Policy 2009, 38, 971-983. [CrossRef]

96. Autre-Terre.; SOS-Faim.; et Iles de Paix. Le baromètre 2019 des agricultures familiales. Défis Sud 2019, 135, 29.

97. CEDEAO. Cadre D'orientation Stratégique à l'Horizon 2025 synthèse; CEDEAO: Abuja, Nigeria, 2017.

98. Dieye, P.N. Les Politiques Agricoles en Afrique Subsaharienne: Une Symphonie Inachevée. Available online: http://www.inter-reseaux.org/publications/revue-grain-de-sel/41-42-1-agriculture-en-quete-de/ article/les-politiques-agricoles-en (accessed on 14 May 2020).

99. Blein, R.; Soulé, B.G.; Dupaigre, B.F.; et Yérima, B.; Les Potentialités Agricoles de l'Afrique de l'Ouest (CEDEAO). Fondation Pour L'agriculture et la Ruralité dans le Monde. Available online: https://www. fondation-farm.org/IMG/pdf/potentialites_etude_mp.pdf (accessed on 29 April 2020).

100. Derra, S. Les Politiques Publiques en Matière de Sécurité Alimentaire dans le Sahel. Available online: http: //grdr.org/IMG/pdf/097_17_grdr-_derra_salif_-_livret_diapoco_2_a4-low-page_a_page_.pdf (accessed on 1 May 2020). 
101. CORAF/WECARD. Impulser L'innovation: Notre Plan Stratégique 2018-2027. Available online: http: //www.coraf.org/wp-content/uploads/2019/03/PlanStrategique.pdf (accessed on 28 June 2020).

102. CORAF/WECARD. Plan Stratégique 2007-2016. Available online: http://www.coraf.org/documents/sri/ PlanStrategique07_016.pdf (accessed on 12 April 2020).

103. Salifou, O. La Politique Agricole Régionale de 1' Afrique de 1 ' Ouest: L' ECOWAP. Available online: http://www.diplomatie.gouv.fr/IMG/pdf/01_ComCEDEAO.pdf (accessed on 6 April 2020).

104. FAO; FAO. Programme détaillé de développement de l'agriculture africaine. Intégration des sous-secteurs élevage, forêts et pêches dans le PDDAA. In Programme Détaillé de Développement de L'agriculture Africaine. Intégration des Sous-Secteurs; FAO: Rome, Italy, 2006.

105. Oxfam. L'ECOWAP: Une Politique Morcelée. Available online: http://www-cdn.oxfam.org/s3fs-public/file_ attachments/bp-ecowap-fragmented-policy-131115-fr_.pdf (accessed on 17 March 2020).

106. CEDEAO. Programme D'appui à L'élaboration et à la Validation du Cadre de Politique Agricole Commune de L'Afrique de l'Ouest. Available online: http://www.hubrural.org/IMG/pdf/cedeao_presentation_processus_ pac.pdf (accessed on 22 May 2020).

107. CEDEAO. Stratégie Régionale de Promotion des Engrais en Afrique de l'Ouest. Sommet Africain sur les Engrains; CEDEAO: Abuja, Nigeria, 2006.

108. CEDEAO, UA, N. Programme Régional D'investissements Agricoles et de Sécurité Alimentaire et Nutritionnelle PRIASAN 2016-2020. Available online: http://araa.org/sites/default/files/media/ PRIASAN2016--2020Français.pdf (accessed on 16 May 2020).

109. Inter-réseaux Développement rural (IRDR) et SOS-Faim. Quel Bilan Pour la Politique Agricole Ouest-Africaine, dix Ans Après son Adoption? Available online: http://www.inter-reseaux.org/IMG/ pdf/bds19_ecowap_mars2016.pdf (accessed on 18 May 2020).

110. Inter-réseaux Développement Rural (IRDR). Sommaire. Revue de Presse Actualité Agricole et Rurale au Burkina Faso. Available online: http://www.inter-reseaux.org/IMG/pdf/revue_de_presse_actualite_agricole_ _burkina_23octobre_au_20_novembre2019.pdf (accessed on 3 May 2020).

111. IFAD. Burkina Faso. Evaluation de la Stratégie et du Programme de Pays Document d'Orientation. Available online: http://www.ifad.org/documents/38714182/40307236/ESPP+Burkina+doc+d\%27orientation_ final_27-03-2018.pdf/b93ee6b9-5b14-440e-aac0-48b5bdb7cb40 (accessed on 21 May 2020).

112. Ministère de l'Agriculture et des Aménagements Hydro-Agricoles du Burkina Faso (MAAH). Deuxième Programme National du Secteur Rural 2016-2020. Available online: http://extwprlegs1.fao.org/docs/pdf/ Bkf184859.pdf (accessed on 11 April 2020). [CrossRef]

113. Laga, S. Mesures de Politique Agricole et Sécurité Alimentaire au Bénin: Cas des Subventions D'intrants Agricoles-Senghor LAGA; Université d'Abomey-Calavi: Cotonou, Benin, 2015.

114. Adjovi-Ahoyo, N.; Glin, L.C.; et Azandegbe, D. Analyse des Interventions du Pouvoir Public Dans le Secteur Agricole au Bénin de 1960 à nos Jours. Available online: http: //www.researchgate.net/publication/261873436_Analyse_des_interventions_du_pouvoir_public_dans_le_ secteur_agricole_au_Benin_de_1960_a_nos_jours (accessed on 22 May 2020).

115. Inter-Réseaux Développement Rural (IRDR). Inter-Réseaux Développement Rural. Available online: http://www.inter-reseaux.org/vie-du-reseau/archives-des-groupes-de-travail/gt-politiques-agricoles/ article/politiques-agricoles-au-benin (accessed on 23 May 2020).

116. Acclassato, D. Ten Yen after the Maputo Declaration on and Agriculture and Food Security: An Assessment of Progress in West Africa Structure and Content of Country Studies. Available online: http://www.roppaafrique.org/IMG/pdf/togo_rapport_final-kf.pdf (accessed on 27 May 2020).

117. PNUD. Rapport National sur le Développement Humain 2015. Agriculture, Sécurite Alimentaire et Développement Humain au Bénin 2015. 144p. Available online: https://www.undp.org/content/dam/benin/ docs/publication/rapportdevhu/RNDH_2015_B\%c3\%a9nin.pdf (accessed on 23 May 2020).

118. ROPPA. Un Autre Cap Pour L'agriculture en Afrique de L'ouest L'agroécologie Paysanne fer de Lance de L'agriculture Familiale et de la Souveraineté Alimentaire Réunion de Lancement du Processus Collaboratif de Réflexion et D'engagement en Afrique de L'Ouest. Available online: http://araa.org/pasanao/files/classified/ roppa_-_compte_rendu_-_rencontre_sur_l_agroecologie_paysanne_-thies_et_dakar_-_avril_2018.pdf (accessed on 28 April 2020).

119. ETD. Un Nouveau Projet au Bénin: Le PROSOL-Entreprise Terrritoires et Développement. Available online: http://etd-ong.org/un-nouveau-projet-au-benin-le-prosol/ (accessed on 18 April 2020). 
120. USAID/IFDC. Guide Pour les Programmes de Subvention. Améliorer la Conception et la Mise en CEuvre des Programmes de Subvention des Engrais en Afrique de L'ouest. Principes Directeurs Proposés Pour des Programmes de Subvention Intelligente. Available online: http://pesquisa.bvsalud.org/bvsms/resource/pt/ mis-9344 (accessed on 22 June 2020).

121. BAD. Perspectives Économiques en Afrique de l' Ouest. Available online: http://www.afdb.org/fr/documents/ document/west-africa-economic-outlook-2018-100849 (accessed on 17 June 2020).

122. Jacquemot, P. Perspectives Économiques pour l'Afrique Subsaharienne. Questions et Scénarios. How Lang. Learn. 2013, 3, 6-33. [CrossRef]

123. Sourisseau, J.M.; Bosc, P.M.; Fréguin-Gresh, S.; Bélières, J.F.; Bonnal, P.; Le Coq, J.F.; Anseeuw, W.; Dury, S. Les modèles familiaux de production agricole en question. Comprendre leur diversité et leur fonctionnement. Autrepart 2012, 62, 159. [CrossRef]

124. Nepad. Les Agricultures Africaines: Transformations et Perspectives. Available online: http://www.un.org/ fr/africa/osaa/pdf/pubs/2013africanagriculturesf.pdf (accessed on 11 May 2020).

125. Jinukun. Etude des Pratiques Agroécologiques au Bénin et Dans Quelques Pays de la Sous-Région. Projet de Soutien à L'Extension de L'Agriculture Agroécologique au Bénin. Available online: http://www.docdeveloppement-durable.org/file/Agriculture/AgricultureBiologique/etude_agro-ecologie_Benin.pdf (accessed on 18 May 2020).

126. Angelucci, F.; Balié, J.; Gourichon, H.; Aparisi, A.M.; et Witwer, M. Suivi et Analyse des Politiques Agricoles et Alimentaires en Afrique Rapport de synthèse 2013. Available online: http://www.fao.org/3/i3513f/i3513f.pdf (accessed on 15 June 2020).

127. PNDES. Plan National de Développement Économique et Social (PNDS), 2016: Plan National de Développement Économique et Social (PNDES) 2016-2020. Available online: http://cns.bf/IMG/pdf/pndes_ 2016-2020-4.pdf (accessed on 4 April 2020). [CrossRef]

128. Lugen, M. Le rôle des services climatiques dans l'adaptation de l'agriculture: Perspectives avec le cas du Burkina Faso. Mondes Dev. 2019, 185, 149-164. [CrossRef]

129. Ibrahim, B. Caractérisation des Saisons de Pluies au Burkina Faso dans un Contexte de Changement Climatique et Évaluation des Impacts Hydrologiques sur le Bassin du Nakanbé; Université Pierre et Marie Curie et de l'Institut International d'Ingénierie de l'Eau et de l'Environnement (2iE) de Ouagadougou: Ouagadougou, Burkina Faso, 2013.

130. Bazie, Y.G.; Le Cotty, T.; Maitre, D.E.; Ouattara, D.O.; Sanou, A. Pourquoi une relation positive entre taille des exploitations et productivité au Burkina Faso ? Économie Rural. 2020, 37-58. [CrossRef]

131. IMCG. Analyse de la Chaine des Valeurs du Sésame au Burkina Faso. Available online: https://europa.eu/capacity4dev/coop-ration-ue-au-burkina-faso/documents/analyse-de-la-chainede-valeur-du-sesame-au-burkina-faso (accessed on 4 June 2020).

132. FAO. Impacts des Systèmes de Production Bovine et Avicole sur les Moyens de Subsistance au Burkina Faso. Filière Bovine et Volaille; FAO: Rome, Italie, 2018; 11p.

133. Tondel, F. Dynamiques Régionales des Filières D'élevage en Afrique de L'Ouest. Etude de cas centrée sur la côte d'ivoire dans le bassin commercial central; Centre européen de gestion des politiques de développement (ECDPM): Maastricht, Pays-Bas, 2019; 44p.

134. Tapsoba, A. Valorisation Économique des Produits Forestiers non Ligneux au Burkina-Faso: Cas de Parkia Biglobosa (Néré); Université De Ouagadougou: Ouagadougou, Burkina Faso, 2014.

135. Kaboret, B.; Sama, P.G.; Zambelongo, P. Stratégie Nationale de Développement de L'accès des Produits Forestiers non Ligneux (PFNL) aux Marchés; United Nation Environment program (UNEP): Nairobi, Kenya, 2018; 33p.

136. Ministère de L'économie Numérique et de la Communition (MENC). Stratégie Nationale Pour L'e-Agriculture au Bénin 2020-2024. Available online: http://assets.fsnforum.fao.org.s3-eu-west-1.amazonaws.com/public/ discussions/contributions/Stratégienationalee-AgricultureBenin25-08-2019.pdf (accessed on 15 June 2020).

137. UNDP et MEPN. Programme D'action National D'adaptation aux Changements Climatiques du Bénin (PANA-BÉNIN). Available online: http://unfccc.int/resource/docs/napa/ben01f.pdf (accessed on 10 May 2008).

138. PADA. Cadre de Gestion Environnementale et Sociale (CGES); Programme Cadre d'Appui à la Diversification Agricole (ProCAD), Cotonou, Bénin 2016. 124p. Available online: https://procad.online/wp-content/uploads/ 2018/08/CGES-PADA-additionnel.pdf (accessed on 15 June 2020). 
139. SICC. Site du Changement Climatique du Bénin. Available online: http://www.changementsclimatiques.bj/ actualites/zones-agro-ecologiques-de-la-republique-du-benin.html (accessed on 10 April 2020).

140. Hounkponou, S.K. Rapport D'étude sur les Impacts des Changements Climatiques et Avancées en Matière D'adaptation. Cas du Bassin de Tèwi dans la Commune de Dassa-Zoumè au Bénin. Available online: www.climatdeveloppement.org (accessed on 17 June 2020).

141. FAO et Commission de la CEDEAO. Profil National Genre des Secteurs de l'Agriculture et du Développement Rural-Bénin. Serie des Évaluations Genre des Pays; FAO et CEDEAO: Cotonou, Benin, 2018; 152p.

142. Alinsato, A.; et Yagbedo, U. Analyse D’ Offre des Produits Maraîchers au Bénin. Available online: http://www. wtochairs.org/sites/default/files/WP2018_Analysed\%27offredesproduitsmaraîchersauBénin.pdf (accessed on 20 May 2020).

143. SOS-Faim. L'Ouest, Les défis des éleveurs: Le cas du Bénin en Afrique de. Dyn. Paysannes 2015, 36. 12p.

144. El Ayoubi, H.; Failler, P. Synthèse de L'Etude sur les Industries des Pêches et de L'aquaculture Bénin. Available online: http://www.researchgate.net/publication/327570044_synthese_de_l\T1\textquoterightetude_ relative_a_l\T1|textquoterightindustrie_des_peches_et_de_l\T1|textquoterightaquaculture_au_Benin (accessed on 16 April 2020).

145. Direction Générale des Forêts et des Ressources Naturelles du Bénin (DGFRN). Stratégie et Plan d'Action Pour la Biodiversité 2011-2020; DGFRN: Cotonou, Bénin, 2013; 116p.

146. Herrera, R.; Ilboudo, L. Les défis de l'agriculture paysanne: Le cas du Burkina Faso. Homme la Soc. 2012, 183-184, 83-95. [CrossRef]

147. New Agriculturalist (NewAg). New Agriculturist: Country Profile-Benin. Available online: http: //www.new-ag.info/en/country/profile.php?a=389 (accessed on 22 March 2020).

148. Westerberg, V.; Golay, A.; Houndekon, V.; et Costa, L. L'économie de la dégradation de terre, le cas de la commune de Banikoara. In Le Coton Est-il Vraiment l'or Blanc à Banikoara; The Economics of Land Degradation (ELD): Bonn, Allemagne, 2017; 53p. [CrossRef]

149. IFDC. Atelier de Validation des Statistiques Engrais 2017 par les Groupes de Travail Technique Engrais Burkina Faso, Côte d'Ivoire, Mali, Sénégal. Available online: http://cote-divoire.countrystat.org/fileadmin/ user_upload/countrystat_fenix/congo/docs/AfricaFertilizer.org\%20-\%20Rapport\%20Atelier\%20GTT\% 20Engrais\%20-\%20Bamako\%20Mai\%202018.pdf (accessed on 2 May 2020).

150. Statistica. Coton: Premiers Pays Exportateurs dans le Monde 2017/2018 | Statista. Available online: http://fr. statista.com/statistiques/550324/premiers-pays-exportateurs-de-coton-monde/ (accessed on 20 May 2020).

151. Hougni, A.; Moreira, A. L'aide au Développement du Coton Avant et Après 2003 et L'initiative C-4: Le cas du Bénin. Available online: http://www.wto.org/english/tratop_e/agric_e/item_8_c_article_hougni_et_ moreira_cottondevassistance_wto2019_fr.pdf (accessed on 9 May 2020).

152. OBjectif-Afrique. Burkina Faso: Création de la première société d'égrenage du coton biologique. Lettre D'information Économique 2020. 21p.

153. Bureau de Restructuration et de Mise à Niveau du Bénin (BRMN). L'industrie de la confection: Une valeur ajoutée à l'exportation. Revue Semestrielle du (BRMN) 2018. 40p.

154. Morin-Kasprzyk, M.; Sankara, R.; et Garnotel, J. Quel accompagnement des producteurs sur la voie de l'agro écologie de la pratique à une démarche. In Burkina Faso_Province du Sanmatenga Synthèse de Capitalisation Septembre 2015; Fert et Accir: Ouagadougou, Burkina Faso, 2015; 35p.

155. Coulibaly, A.; Nebie, M.; Yougbare, S.; Savadogo, C.A.; Sawadogo, J.D.D.; Traore, M.; et Zemba, P. Analyse des Parties Prenantes du Secteur de L'agriculture Biologique et de L'agroécologie au Burkina Faso: Résultats par la Méthode RAAKS; Organic market for developement (OM4D): Bonn, Allemagne, 2018; 45p.

156. Inter-réseaux Développement rural (IRDR) et SOS Faim. Agroécologie: Où en est-on? Bulletin de Synthèse Souveraineté Alimentaire 2011. 8p.

157. Veillard, P. Qu'est-ce que l'agroécologie? in Dossier: L'agroécologie, une solution ? Défis Sud 2011, 103, 8-11.

158. Dia, A.; et Niang, A.M. Introduction. L'Initiative africaine de la Grande Muraille Verte (IAGMV): Contexte, vision et opérationnalisation. In La Grande Muraille Verte 9-35; Institut de recherche pour le développement (I.R.D): Marseilles, France, 2016. [CrossRef]

159. Bamba, O.; Pelede, S.; Sako, A.; Kagambega, N.; et Miningou, M.Y.W. Impacts de l'artisanat minier sur les sols d'un environnement agricole aménagé au Burkina Faso. J. Sci. 2013, 13, 1-11.

160. Bohbot, J. L'orpaillage au Burkina Faso: Une aubaine économique pour les populations, aux conséquences sociales et environnementales mal maîtrisées. EchoGéo 2017, 31, 1-19. [CrossRef] 
161. Konkobo, H.M.; Sawadogo, I. Exploitation Minière Artisanale et Semi-Mécanisée de l'or au Burkina Faso: Les Acteur·Trice·s de la Chaîne Opératoire, Leur Vécu Quotidien et Leurs Perceptions des Tentatives Actuelles D'encadrement et de Formalisation. Available online: http://www.land-conflicts.fu-berlin.de/_media_design/ country-reports/Country-Report_Burkina-Faso_5.pdf (accessed on 20 May 2020).

162. FAO et WFP. Burkina Faso Réponse Conjointe 2019-2020 Soutenir les Activités Agricoles et Pastorales Pendant la Contre-Saison, Afin D'améliorer la Sécurité Alimentaire des Ménages Touchés par L'insécurité; FAO et WFP: Ouagadougou, Burkina Faso, 2019; 11p.

163. Grenade, F. Systèmes Alimentaires Durables au Sud Obstacles et Pistes Pour Relever le Défi; Coalition contre la faim: Bruxelle, Belgique, 2019; 24p.

164. ROPPA et IPES Food. Il est Temps que le Mouvement Agroécologique Ouest-Africain Unisse sa Voix'. Available online: https://www.pfongue.org/IMG/pdf/3ao_communique_de_presse.pdf (accessed on 7 May 2020). [CrossRef]

165. ROPPA. Décennie de l'Agriculture Familiale; ROPPA: Banjul, Gambie, 2018; 30p. [CrossRef]

166. UNI4COOP. Programme Commun 2017-2021 Partie 1 et 2. Available online: http://aidstream.org/files/ documents/Partie1Uni4Coop2017-2021-20180316080338.pdf (accessed on 11 April 2020).

167. Ouedraogo, F. Groupements de femmes rurales au Burkina Faso: Enjeux et défis pour un développement durable. Entraide et Fraternité 2018. 10p.

168. SOS-Faim. Agroécologie, un modèle qui tient la route? Des principes à la pratique avec Apil au Burkina Faso. Dyn. Paysannes 2017. 12p.

169. Bellon, S. Contributions croisées de l'agriculture biologique à la transition agroécologique. Innovations Agronomiques. Innov. Agron. 2016, 51, 121-138.

170. FAO. 2ème Symposium International sur L'agroécologie: L'agroécologie au Service des ODD_Passer à L'échelle Supérieure 3-5 Avril 2018, Rome Résumé du Président; FAO: Rome, Italie, 2018; 9p.

171. Coulibaly, M. Vers une transition Agroécologique au Burkina Faso. Expériences D'organisations Paysannes 2017. 17p.

172. Meynard, J.-M. L'agroécologie, un nouveau rapport aux savoirs et à l'innovation. OCL Oilseeds Fats Crop. Lipids 2017, 24, 1-9. [CrossRef]

173. Vidogbèna, F.A.H. Adoption du Filet Anti Insectes Pour la Protection du Chou Pomme (Brassica Oleracea L.) En Milieux Urbain et Périurbaine du sud Bénin (Afrique de L'ouest); Université d'Abomey-Calavi: Cotonou, Benin, 2017.

174. Bélières, J.-F.; Bosc, P.-M.; Faure, G.; Fournier, S.; Losch, B. Quel Avenir Pour les Agriculture s Familiales D'afrique de l'Ouest Dans un Contexte Libéralisé? Available online: https://pubs.iied.org/pdfs/9277IIED.pdf (accessed on 1 May 2002).

175. Brossier, J.; Dugué, P.; Gafsi, M.; et Jamin, J.-Y. Exploitations Agricoles Familiales en Afrique de L'Ouest et du Centre; Éditions Quæ: Versailles, France, 2007; 475p.

176. Ajzen, I. The theory of planned behavior. Organ. Behav. Hum. Decis. Process. 1991, 50, 179-211. [CrossRef]

177. Ferrato, N.; et Touzard, I. Comprendre L'agriculture Familiale Diagnostic des Systèmes de Production. Agricultures Tropicales en Poche; Quæ, C.T.A., Ed.; Presses agronomiques de Gembloux: Gembloux, Belgium, 2009; 135p.

178. FENOP. Numéro spécial Agroécologie. In Le magazine du monde rural burkinabé; Numéro spécial Septembre 2015; FENOP: Ouagadougou, Burkina Faso, 2015; pp. 1-23.

179. FENOP. Rencontre Régionale à Dakar sur l'agro écologie en Afrique Subsaharienne. In Le Magazine du Monde Rural Burkinabé; FENOP: Ouagadougou, Burkina Faso, 2015; pp. 2-3.

180. Clavel, D.; Barro, A.; Belay, T.; Lahmar, R.; et Maraux, F. Changements techniques et dynamique d'innovation agricole en Afrique Sahélienne: Le cas du Burkina Faso et de l'introduction d'une cactée en Ethiopie. Vertigo 2008, 8, 18. [CrossRef]

181. Belemvire, A.; Maiga, A.; Sawadogo, H.; Savadogo, M.; et Ouedraogo, S. Etude Sahel Burkina Faso. Évaluation des Impacts Biophysiques et Socioéconomiques des Investissements Dans les Actions de Gestion des Ressources Naturelles au Nord du Plateau Central du Burkina Faso. Rapport de Synthèse Version Provisoire. Available online: http://portails.cilss.bf/IMG/pdf/etudesahelrapportBF.pdf (accessed on 14 May 2008).

182. AGRIDAPE. Femmes et agroécologie. Revue sur L'agriculture à Faible Apports Externes 2015, 31, 28. 
183. IED. Un Réseau de Fermes Agroécologiques Pour Autonomiser des Femmes au Togo et au ( ... ) —IED Afrique | Innovations Environnement Développement. Available online: http://www.iedafrique.org/Un-reseau-defermes-agroecologiques-pour-autonomiser-les-femmes-au-Togo-et-au.html (accessed on 30 March 2020).

184. Terre verte. WÉGOUBRI, le Bocage Sahélien Intégrer la Sauvegarde de L'environnement dans L'agriculture Sahélienne au Burkina Faso. Available online: https://azn-guie-burkina.org/les-activites-de-lassociation/ la-ferme-pilote-de-guie-lagro-environnement-selon-lazn/wegoubri-le-bocage-sahelien/ (accessed on 29 May 2020).

185. Barro, N.B. Les Défis Sociologiques de l'Adoption des Technologies Agro Écologiques par les Maraichers Dans la Commune de Bobo Dioulasso: L'Exemple des sites Maraichers de Kuinima, Leguema et Kua. (Université Catholique de l'Afrique de L'ouest (UCAO); Unité universitaire à Bobo-Dioulasso (UUB): Bobo-Dioulasso, Burkina Faso, 2019.

186. Finet, M.; et Derkimba, A. Pour Une Transition Agroécologique dans les Territoires Soumis à la Desertification Proposition D'une Démarche D'accompagnement. Available online: http://www.gtdesertification.org/IMG/ pdf/GTD_2015-Agroecologie-territoires-12Mo.pdf (accessed on 7 June 2020).

187. Giller, K.E.; Witter, E.; Corbeels, M.; Tittonell, P. Field Crops Research Conservation agriculture and smallholder farming in Africa: The heretics' view. F. Crop. Res. J. 2009, 114, 23-34. [CrossRef]

188. GOÏTA, M. Les défis du développement agricole en Afrique et le choix du modèle: Révolution verte ou agroécologie? Sos Faim 2014. 39p.

189. Capacity Development for Agricultural Innovation System(CDAIS). Conversation of change Burkina Faso. Available online: http://cdais.net/wp-content/uploads/2019/08/CDAIS-2019-Conversations-of-ChangeBurkina-Faso.pdf (accessed on 15 August 2020).

190. Ministère de L'Agriculture et des Aménagements Hydro-Agricoles du Burkina Faso (MAAH). Politique Sectorielle Production Agro-Sylvo-Pastorale 2018-2027. Available online: http://spcpsa.bf/wpcontent/uploads/2018/11/Politique-Sectorielle-Production-Agro-Sylvo-Pastorale-2018-2027.pdf (accessed on 9 May 2020). [CrossRef]

191. Brondeau, F. Comment sécuriser l'accès au foncier pour assurer la sécurité alimentaire des populations africaines: Éléments de réflexion. Vertigo 2014, 14, 1-7. [CrossRef]

192. Souratié, M.; Koinda, F.; Samandoulougou, R.; et Decaluwé, B. Politiques Agricoles, Emploi et Revenu des Femmes au Burkina Faso: Comment l'accès des Femmes aux Ressources Productives Peuvent Améliorer Leurs Conditions de Vie et Stimuler L'économie; Partenership for economic policy: Nairobi, Kenya, 2019. [CrossRef]

193. Chauveau, J.P.; Colin, J.P.; Jacob, J.P.; Delville, P.L. et Le Meur, P-Y. Modes d'accès à la terre, marchés fonciers, gouvernance et politiques foncières en Afrique de l'Ouest. Résultats du Projet CLAIMS 2006, 98p.

194. Utviklingsfondet. Un Avenir Alimentaire Viable; Utviklingsfondet: Oslo, Norvège, 2011; p. 68P.

195. FAO. Situation Mondiale de L'alimentation et de L'agriculture; FAO: Rome, Italie, 2011; 174p. [CrossRef]

196. Basquin, H.; Charhon, F.; Cissokho, M.; Le Gauyer, G.; Rouillé d'Orfeuil, R.; et Vielajus, J.-L. Nourrir les Villes, Défi de L'agriculture Familiale des Innovations Locales et Paysannes en Afrique de l'Ouest; CFSI et Fondation de France: Paris, France, 2014; p. 112p.

197. Eloy, D.; Diagne, D.; Basquin, F.H.; Bagna, D.; Cosquer, M.; Drique, M.; Duquesne, I.; Érard, P.; Gnassingbé, S.A.; Lejeune, I.; et al. Les Batailles du Consommer Local en Afrique de L'ouest; CFSI et Fondation de France: Paris, France, 2019; 128p.

198. Urgenci. Retisser le Lien Cassé Entre Producteurs et Consommateurs: Cartographie des Partenariats Locaux et Solidaires en Afrique de L'Ouest; Urgenci: Normandi, France, 2018; 59p.

199. UNFPA. Rapport sur les Adolescents et Les Jeunes: Afrique de l'Ouest et du Centre Africa. Available online: http://reliefweb.int/sites/reliefweb.int/files/resources/UNFPA-WCARO-YOUTH-FR-WEB_ FINAL.pdf (accessed on 27 May 2020).

200. AGRIDAPE. Agriculture durable et insertion des jeunes. Revue sur L'agriculture à Faible Apports Externes 2018. $34 \mathrm{p}$.

201. ECLOSIO. L'agroécologie: Reconnecter L'homme à son Écosystème Novembre. Available online: http: //www.eclosio.ong/wp-content/uploads/2018/09/agroecologie.pdf (accessed on 23 June 2020).

202. SOS-Faim. Revendiquer des opportunités locales, refuser la concurrence déloyale. Défis Sud 2020. 100p.

203. Rastoin, J.-L. Systèmes alimentaires territorialisés au québec100 initiatives locales pour une alimentation responsable et durable. J. Resolis 2016, 7,61.

204. Rossetti, P. Accompagner les Paysans Sahéliens dans la Prise de Risque d'une Reconversion Agroécologique; Institut d'Études Politiques de Lyon: Lyon, France, 2014. 
205. Chantre, E.; LeBail, M.; Cerf, M. Une diversité de configurations d'apprentissage en situation de travail pour réduire l'usage des engrais et pesticides agricoles. Activites 2014, 11, 2-25. [CrossRef]

206. Coquil, X.; Blouet, A.; Fiorelli, J.L.; Bazard, C.; Trommenschlager, J.M. Conception de systèmes laitiers en agriculture biologique Une entrée agronomique. Prod. Anim. 2009, 22, 221-234.

207. AGRIDAPE. L'impact de l'agroécologie en questions. Revue sur L'agriculture à Faible Apports Externes 2016. 32p. 